\title{
Relativism and Universalism in Interrogation Fairness: a Comparative Analysis between Europe and China
}

\author{
Wei Wu and Tom Vander Beken
}

\begin{abstract}
[Abstract]
This paper addresses Chinese interrogation rules from historical and comparative perspectives by relating them to the very different development of interrogation procedure in Europe. A fuller understanding of the evolution of the rules in both contexts is relevant to the present day controversy concerning the universal versus relative nature of interrogation fairness. The comparative analysis reveals that, in fact, the influence of ancient Greek and Chinese civilizations resulted in a great difference between Europe and China regarding legal cultures and institutional arrangements for criminal interrogation procedure. Considering future legal reforms in China, and given the very different historical and institutional context, the likelihood seems low that an 'autonomous version' of the right to remain silent and the privilege against selfincrimination will develop on China's very different soil. However, traditional native resources are also available to legal reformers to ensure a cooperative interviewing style in criminal questioning, and eliminate police-coerced confessions.
\end{abstract}

\section{Introduction}

In recent years, a number of high profile wrongful convictions have plagued the Chinese criminal justice system. ${ }^{1}$ While each of these cases has raised serious questions concerning the justice system as a whole, particular attention has been directed towards the police and their ability to satisfy their dual mandate to investigate a crime while protecting the rights and freedoms of the accused. One notable aspect of police operations that has come under increasing scrutiny in this regard is the police interrogation, a practice which is both upheld by police officers as a crucial means of gathering information and disposing cases, and denounced by legal scholars and civil rights advocates as a serious threat to the standards of fairness and due process ( $\mathrm{Wu}, 2006 \mathrm{a}$; Chen, 2007). Many Chinese

${ }^{1}$ For instance, in 2005, the wrongful convictions of Li Jiuming, Nie Shubin, and She Xianglin precipitated a growing crisis of legitimacy within the Chinese criminal justice system (Chen, 2007:54). 
scholars, relying on different sources, including interviews with present and former law enforcement officers or individual field observations, have made the alarming assertion that the malady of confessions produced by torture ${ }^{2}$ (xingxunbigong, 刑讯逼供) has been widespread in China (Wu and Vander Beken, 2010). The majority view among researchers was that dominated by ideology of 'crime control' rather than 'due process', the current Criminal Procedure Law (CPL) of the People's Republic of China (PRC) and relevant supplementary regulations fail to provide the suspect with adequate safeguards against pernicious interrogation practices (Zuo 2005; Bi 2007).

In fact, the problem of coercive police confession has been so pervasive in China that it has captured the attention not only of domestic academic scholars but also of the international community. ${ }^{3}$ In the face of such 'devastating' issues, unsurprisingly, the growing power of the international human rights movement has led to a backlash in China (Peerenboom, 2003:1). Notably, activists have argued that there is a significant level of consensus regarding 'the presumption of innocence' and 'the privilege against self-incrimination' as set forth in the Universal Declaration of Human Rights (UDHR), ${ }^{4}$ and the International Covenant on Civil and Political Rights (ICCPR) ${ }^{5}$ (Gelatt, 1982). Hence, in the name of universal human rights, rights activists urge the PRC to comply with these 'universal' norms (Gelatt, 1982).

The Chinese government, however, has raised serious challenges to this claim of universality, arguing that all moral values, including human rights, are relative to the social and cultural context in which they arise (Peerenboom, 2003), and the law's very existence depends on its interpretation and application within an interpretative community, which is historically and culturally conditioned (Zhu, 2007). In particular, the government feels uneasy about some 'undeniable' principles in western criminal procedures, such as the presumption of innocence and the privilege against self-incrimination (Gelatt, 1982; Ren, 2007). The officials in the legislative body of the Standing Committee of the

${ }^{2}$ The Chinese academics define torture in a broader sense than the CAT does. They define torture as any act by which corporal treatment or quasi-corporal treatment is inflicted by judicial officers on a suspect or defendant to extract confessions (Zhe, 2005). Corporal treatment refers to physical coercion through inflicting pain directly on the body, such as a beating or imparting an electric shock. Quasi-corporal treatment refers to physical or psychological coercion through inflicting pain (physical or mental) indirectly on the body, such as through sleep deprivation, exposure to cold or heat, or being forced to sit or stand in uncomfortable positions.

${ }^{3}$ See, for instance,

http://www.amnesty.org/en/library/asset/ASA17/094/2008/en/bb7a7607-8f0b-11dd8d03-3f760a3cc4a3/asa170942008en.pdf and

http://www.falunhr.org/reports/PDFs/ShadowReportOnChina2008.pdf.

${ }^{4}$ Article 11 of the UDHR.

${ }^{5}$ Article 14 of the ICCPR. 
National People's Congress explained that the Chinese approach to criminal investigation is to engage neither in the 'presumption of guilt' nor in the 'presumption of innocence' (Ma and Li, 1999: 63). The Chinese criminal procedure does not presume anything-it lets evidence and facts speak (Gelatt, 1982).

Competing claims about the universal versus relative nature of interrogation fairness reflect one of the main challenges confronting international legal instruments and comparatists: how can the competing claims of cultural relativism and fair universal interrogation standards be reconciled? This paper addresses the Chinese interrogation rules from a historical and comparative perspective by relating them to the very different development of police interrogation procedure in Europe. The purpose of this comparative analysis is twofold. On the one hand, only after a deeper understanding of different social and legal systems can one begin to ascertain the proposition that, in the area of interrogation procedure, there exists a 'common core' of problems among various legal systems, notwithstanding momentous differences in political, cultural, and legal outlooks. On the other hand, by exploring the historical, political, and philosophical backdrop of current Chinese reforms, it is easier for (Western) legalists to understand how the right and the privilege in China will develop along a different path.

This paper is structured as follows. The first section documents the rise of ancient Greek and Chinese civilizations from roughly the eighth to the third century B.C. and illustrates their implications for European and Chinese legal cultures. This is followed by an analysis of the evolution of criminal interrogation rules in Europe. The paper will then focus on the history of criminal interrogation rules in China, for which a comparative analysis is provided. The last section presents the conclusion.

\section{Ancient Greek and Chinese Civilizations: Different Perspectives on Law}

From roughly the eighth to the third century B.C., many civilizations made great strides in philosophical and moral thought, notably those of Greece and China. The influence that each of these two civilizations has had on the world is particularly great. Greek civilization nurtured the Western legal culture, and Chinese civilization gave rise to the legal culture of East Asia. 


\subsection{Greek Civilization and Law as an Autonomous Institution}

One of the most remarkable characteristics of the ancient Greeks was the vesting of power in the individual. It is observed that ordinary Greek people developed a sense of personal agency that had no counterpart among the other ancient civilizations (Nisbett, Peng, Choi, and Norenzayan, 2001:292). Indeed, one definition of happiness for the Greeks was the exercise of vital powers along lines of excellence in a life affording them scope' (Hamilton, 1973:25). Though the Greeks believed that the secular order was influenced by the gods, 'divine intervention and independent human action' were seen to work together (Knox, 1990:39). The daily lives of the Greeks were imbued with a sense of choice and an absence of social constraint that were unparalleled in the ancient world. According to Hamilton, 'The idea of the Athenian state was a union of individuals free to develop their own powers and live in their own way, obedient only to the laws they passed themselves and could criticize and change at will' (1973:144). As Wieacker (1981:263) showed, in the developed Greek polis, 'law' was not conceived of as a divine gift or an immemorial custom, but rather as a man-made, autonomous institution.

Related to the Greek sense of personal freedom was the tradition of debate, which was already well established by at least the time of Homer in the $8^{\text {th }}$ century (Galtung, 1981; Lloyd, 1990). Homer emphasizes repeatedly that, next to being a capable warrior, the most important skill for a man to have was that of a debater. Even ordinary people participated in the debates of the political assembly and could challenge even a king (Cromer, 1993:65).

An aspect of Greek civilization that had a great effect on posterity was their sense of curiosity about the world and the presumption that it could be understood by the discovery of rules (Lloyd, 1991; Toulmin and Goodfield, 1961:62). The Greeks focused on salient objects and used rules and categorization for purposes of describing and explaining the environment (Nisbett, Peng, Choi, and Norenzayan, 2001:292). In particular, recognition that the law was manmade led the Greeks to question the moral basis of human laws. This at the same time raised the problem of why laws are binding. How can law bind the conscience of an individual? Wherein lies the ethical foundation of the coercive power of the state's legal and moral order? For, if an eternal, immutable law obliges men to obey a particular secular law, there must exist behind the popular images of tribal deities 'an eternal, all-wise lawgiver who has the power to bind and to loose' (Rommen and Hanley, 1947:4-5). In fact, the Greeks speculated a great deal about the philosophical conception of natural law and about the law's place in society. 
Although the Greeks never developed an autonomous legal science ${ }^{6}$, their refinement of the concept of law and its philosophy and rhetoric were instrumental in the formation of Roman jurisprudence. The Romans did not give much attention to the theory of law; their philosophy was largely borrowed from the Greeks. Nevertheless, the detailed rules of Roman law were developed by professional jurists and became highly sophisticated. Specifically, the very technical superiority of the reasoning behind Roman laws developed through the categorizing of legal practices and generating of rules about them for the purpose of systematic explanation (Wieacker, 1981:268). Eventually, Roman jurisprudence reached its height in Justinian's Code, which absorbed all the extracts from the writings of the greatest jurists. The large amount of material summarized in the term 'Roman law', according to Wieacker (1981: 257), provided the basis for the rational character of the Western legal systems and the legalism of the Western world.

\subsection{Chinese Civilization and Law as an Instrument for Maintaining Social Order}

This picture of the Greeks provides a basis with which to contrast the ancient Chinese. The Chinese counterpart to the Greek sense of personal agency was a sense of reciprocal social obligation or collective agency. According to Hansen (1983: 30), a fundamental intellectual difference between the Chinese and the Greeks was that the Chinese held the view that the world is a collection of overlapping and interpenetrating stuffs or substances...[This contrasts] with the traditional Platonic philosophical picture of objects which are understood as individuals or particulars which instantiate or "have" properties'. The profound difference in metaphysics had many ramifications, for instance, the Chinese, unlike the Greeks, were inclined to feel that individuals are part of a closely-knit collectivity and that the behaviour of the individual should be guided by the expectations of the relationships in the community (Hamilton, 1984:408; Nisbett, Peng, Choi, and Norenzayan, 2001).

These different metaphysical beliefs also resulted in great differences between Greece and China in their approach to philosophical questions. It has been argued that the Chinese tended to engage in context-dependent and holistic perceptual processes by attending to the relationship between the object and the context in which the object is located (Nisbett and Miyamoto, 2005). Confucianism, which is the dominant Chinese philosophy, is a prime example of this holistic approach. Notably, one fundamental goal of Confucianism is to

\footnotetext{
${ }^{6}$ The positive laws of the various Greek states were not highly developed in the sense that Greeks did not have a class of legal professionals or state officials who monopolized the production of law or the delivery of legal services (Tamanaha, 2004:7; Lesaffer and Arriens, 2009:77).
} 
achieve a harmonious social order in which each person is able to realize his or her full potential as a human being through mutually beneficial relations with others (Peerenboom, 2002:28). Emphasizing the individual's self-consciousness to maintain the social order, Confucians believed that the codification and public dissemination of laws sends the wrong kind of message (Peerenboom, 2002; Windrow, 2006). In Confucius' words, 'lead the people with government regulations and organize them with penal law (xing, 刑), and they will avoid punishments but will be without shame. Lead them with virtue and organize them through the $l i$ (礼), and the people will have a sense of shame and moreover will become humane people of good character' (Analects, 2: 3). Theoretically, the early Confucian view leaves little room for the operation of codified law and punishment.

Since $l i$ have often been construed as universal ethical principles, they have been depicted as kinds of natural law. However, as Peerenboom (2002: 31) explained, 'the $l i$ are better understood as customary norms that gain favour within a particular historical tradition at a particular time'. Indeed, since there is an emphasis on change in Confucian philosophy, $l i$ were merely historically contingent norms founded on experience-based knowledge. It has been maintained that the Chinese never developed a concept corresponding to 'natural law' for the sufficient reason that they did not have a concept of 'nature' as distinct from human or spiritual entities (Munro, 1969; Fung, 1983; Zhou, 1990; Lloyd, 1991).

Notably, although early Confucian ethics evidence poor opinions of law, they were rivalled from the very beginning. Legalism (fajia, 法家) that had arisen during the early Warring State period (475-221 B.C.) advocated a social control program, which was in direct conflict with Confucian ideals. In the legalistic view, human beings are naturally greedy and selfish. Thus, virtue cultivation and moral examples are inadequate to maintain the social order because people's base instincts will constantly drive them to wrongful behaviour (Ren, 1997). The only way to make people behave correctly and to achieve a wellordered society is by an impartial system of rewards and punishments. Specifically, legalists advocate centralization of a ruler's authority through creation of a vast bureaucracy and extensively written laws, and the use of harsh, universally enforced penal code to ensure compliance with state policy. They believe that if even minor infractions are ruthlessly punished, then no one will dare to commit serious crimes (Shang Jun Shu, 17:3). It is seen clearly that legalistic law is one of the means to serve the interest of the ruler, not necessarily the common people. Additionally, legalistic ideas can hardly be regarded as a result of scientific theory and the use of formal logic. Instead, they are reflective of the Chinese genius for practicality. 


\section{The Evolution of Criminal Interrogation Rules in Europe}

\subsection{The Development of the Ideas of Natural law, the Rule of Law, and Legal Rational Domination in Medieval Europe}

During the fifth century, the Western Roman Empire gradually disintegrated in the face of continuous pressure from Germanic tribes. As Roman authority disintegrated, from the sixth until the eleventh century, Europe entered an age of decline and disruption: the Dark Middle Ages. Culturally speaking, the Germanic conquerors of the Roman Empire lagged behind the Romans. In Lesaffer and Arriens's (2009: 123) words, '[the Germans] proved incapable of maintaining Roman civilization or of replacing it with anything worthy of the name'. The law that prevailed in the early kingdoms was essentially the Germanic custom of the rulers. ${ }^{7}$ Although the Germans had retained the enactment of the Byzantine emperors together with some epitomes of elementary legal literature, these collections reflected a low level of legal science compared to the scope and complexities of the Justinian's complication (Wieacker, 1981:273-274). Moreover, the Roman texts often proved to be beyond the comprehension of those who consulted them.

The disappearance of Roman law accompanied the withering away of legal education and professional jurists who handed down judicial opinions by scientific reasoning. In place of the imperial system of courts were tribal assemblies in which the freemen of a given tribe sought to forestall interfamily vendettas and, more importantly, to facilitate negotiation and mediation between hostile families (Berman, 1983). During trials, customary rules were not applied rigidly. Rather, the tribal leaders would generally seek to persuade the parties to resolve a dispute amicably and reach a compromise (Stein, 1999:38). When the parties could not be reconciled, the community courts decided on a method of proof, often leaving vital points to be established by the 'judgment of God'. Such judgment was ascertained by ordeals, duels, or the procurement of oath-helpers (Baldwin, 1961; Brown, 1975). All these forms of inquisition for guilt imply a low level of intellectual development. As Berman (1983: 77-78) rightly demonstrated, in settling criminal disputes, guilt was not determined by

${ }^{7}$ During that time, Europe consisted of a multiplicity of tribal, local and lordship units, which came to share a common religious faith and common military loyalty to the emperor and kings. Nevertheless, prior to the eleventh century, royal and ecclesiastical authorities did not attempt to alter in any fundamental way the essential tribal and feudal character of the legal orders of Europe (Berman, 1983:5152). Thus legal orders prevailing among the peoples of the Continent during that period were primarily tribal in nature. 
applying legal rules; rather, people's superstitious beliefs and unconscious ideas influenced judgments.

Nevertheless, the turning point came during the decades before and after the eleventh century. In fact, with the Christian Church emerging as an independent political entity under the papacy, a higher view of the law was established in Western Christendom. According to Christianity, there exists a universal ecumenical law above local traditions and enactments (Wieacker, 1990:12). Notably, while Greek thought was largely lost under the rule of the Germanic West during the Middle Ages, the concept of natural law found its way into early medieval theology. The fathers of the early Church made use of Stoic natural law to support the Christian doctrine of the personal Creator-God as the author of the eternal law as well as of the natural moral law promulgated in the voice of conscience and reason (Rommen and Hanley, 1947:35). The Church Fathers Origen (181-254), Augustine (354-430), and Isidore of Seville (560-636) further claimed that all secular law, including the canon law of the Church, should be in accordance with natural or divine law to be valid (Lesaffer and Arriens, 2009:183). Nonetheless, a new philosophy and a new world order did not follow at once upon the entrance of the Christian faith into the Germanic world; prior to the late eleventh century, Christianity was for the most part an otherworldly faith (Rommen and Hanley, 1947:30). The Papal Revolution, however, made Christianity into a political and legal program. Christianity became the prevailing religious ideology. Accordingly, law came to be seen as the very essence of faith and as a way of fulfilling Western Christendom's mission to achieve the kingdom of God on earth (Berman, 1983:521).

The religious cloak over understandings of law and society in medieval times in fact laid the groundwork for the concept of the rule of law in the West. According to this concept, rulers should be subject to divine law and the positive law, which they themselves lawfully enacted. To be sure, with the Gregorian Reform, religious faith became individualized and privatized. The emphasis of Christianity shifted from collective salvation to the salvation of each individual soul, and from the Last Judgment of mankind as a whole at the end of times to individual judgment upon each person's death (Lesaffer and Arriens, 2009; Finer, 1999:24). Hence, under the new theology, the individual could participate in the worship with his own inalienable tie to God. Under this understanding, the ruler had no superior status. He was one with his fellow-believers in having to obey divine law (Finer, 1999:25-26). Consequently, believers had the right and duty to disobey the divinely appointed ruler when he violated fundamental law. This, as discussed above, was based on the belief that fundamental law was itself divinely instituted. Popes and kings made laws, but they did so as deputies of God, acknowledging that not they but 'God is the source of all law' (Berman, 1983; Tamanaha, 2004:23). In this sense, for the first time in Western history, 'law' provided the ideology and social cohesion for rebellion and reform 
movements at the same time as it served to legitimate and reinforce the social order.

The concept of the rule of law or impersonalized obedience to law was supported by a high level of legal consciousness and legal sophistication that came to prevail throughout Europe in the late Middle Ages. As Hamilton (1984: 410) noted, the tension regarding personal power between position holders and non-position holders, or between kings and people, favoured the development of a systematic means of defining jurisdictions within which the right of command is deemed legitimate. This increasingly became the function of law. Therefore, as a principle of domination applied in practice, the theme of personalized authority became the object of codification in institutionalizing the legal and economic idea of property, as well as political and philosophic ideas of freedom and reason (Hamilton, 1990:96). Of course, the law of the Middle Ages did not embrace norms and rights identical to those of the twenty-first century. Nevertheless, this does not undercut the conclusion that the medieval canonists and jurists understood and endorsed the notion that natural rights existed and could be asserted by individuals (Tierney, 1997; Helmholz, 2002:303-304). Law factually provided the formal means that allowed both kings and people to preserve personal spheres of power. According to Weber (1968), it is this legalism or legal rational domination that most distinguishes European civilization from that of other high cultures, such as China's, in which law emanates from an accepted social ethic rather than the logic of authority.

Notably, in the general context of a movement towards more rational legal procedure, the Fourth Lateran Council of 1215 abolished the old system of trials by ordeal. The attempt to make God the fact finder for human disputes was thus abandoned (Baldwin, 1961:613). Since mortal judges were going to replace God in finding and deciding guilt or innocence, it was well understood that the preservation of legality required not merely abstract perceptions of justice and equality but also specific principles and rules. Hence, the theme of legalism led to the systematization of jurisprudence and to a legal framework regulating the 'free' will of legal officials in truth-finding processes (Posner, 1990:6-7). As Wieacker (1990: 9-19) argued, from successive re-shapings of the sources of jurisprudence, there arose what moderns recognize as European legal civilization. More specifically, the history of the European legal civilization and interrogation jurisprudence can be divided roughly into two main stages, each of them captured by its own distinctive formulation of the legal science.

\subsection{Late Middle Ages and Early Modern Age: Divine Law and the Obligation to Answer}

In the late Middle Ages, secular law and jurisprudence were largely based upon the tenets of natural and divine law, laws that God himself had created 
and implanted in authoritative texts. For medieval jurists, all Greek, Roman and early Christian writings, especially the newly discovered Roman law of Justinian and canon law, ${ }^{8}$ shared to some extent the authority of the Bible (Berman, 1983:122; Lesaffer and Arriens, 2009: 253-254). These authoritative materials were treated by the jurists as data to be observed, classified, and systematically explained in terms of concepts of truth and general principles (maxims) (Stein, 1999). Several maxims of the ius commune 9 expressed the most important limitation on the judge's power to convict. These maxims preserved the medieval view that human testimony was a form of proof whose probative value could not be weighed (Jackson, 1988:552). Under this rationale, only two forms of evidence could provide proof 'as clear as the noonday sun': noncontradictory testimony from two eyewitnesses, or confession by the accused (Langbein, 1977). This meant convictions of crimes could be pronounced only based on the testimony of two eyewitnesses or the confession of the accused. All other forms of circumstantial evidence, known as indicia, were hierarchically arranged and assigned numerical values. With only one eyewitness and several indicia there could be no conviction (Peters, 1985:69). Moreover, the ius commune insisted that a judge adhere strictly to the rules of law and acquit a suspect if the proof were imperfect: 'the judge must decide according to the allegations and the laws, not according to his conscience' (Fraher, 1989:24).

Nevertheless, the rules of evidence in the ius commune were largely aspirational-a set of norms that look good on paper but were not enforced, because the required witnesses were seldom available, and, in the view of the draconian punishments, voluntary confessions were also in short supply. Since covert crimes do not generate eyewitness testimony, and since no amount of circumstantial evidence could substitute for the testimony, Langbein (1977: 5-8) argued that medieval civil and canon legal systems turned to torture in order to satisfy the alternative requirement of confession. Consequently, from the inception of the inquisitorial procedure, the examination of the suspect was considered the principal mechanism for discovering truth (Damaska, 1978:875). According to the Roman-canon procedure, ${ }^{10} \mathrm{a}$ judge was allowed to put a direct question to a suspect regarding his guilt whenever (1) the suspect was under infamy for the crime, that is, when he was publicly known to have committed the crime; or (2) when there was clear circumstantial evidence; or (3) when the

8 Originally, canon law lacked an authoritative body of texts comparable to Justinian's corpus. Nevertheless, by the 1160s, the civil lawyers recognized canon law as a discipline parallel to civil law, with parity of esteem (Stein, 1999:49)

9 The term ius commune refers to the combination of Roman and canon law that dominated European legal education before the modern era. In large measure, it also determined the rules of practice in the courts of the Latin West (Helmholz, 1997).

10 As Langbein (1974: 129) shows, by the sixteenth century, Roman-canon inquisitorial procedure was visible nearly everywhere one would think to look on the European continent: Spain, Italy, Sweden, German Empire, France, and the Spanish Netherlands. 
testimony of one immediate witness could be brought forth against the suspect. If any of these three conditions were fulfilled, the judge could question the suspect concerning his crime, and he was legally bound to answer truthfully and unambiguously (Connery, 1955:181; Langbein, 2004:95). The violation of these legal duties (silence) constituted one of the indicia required for the interlocutory order to apply torture (Damaska, 1978:875). Moreover, when the evidence strongly tended to establish the suspect's guilt but the suspect still refused to confess, torture would be applied to induce a confession (Langbein, 1977:2004).

Although the system of judicial torture was never known in England, ${ }^{11}$ there had been a broad consensus among European jurists that it was legitimate to require a particular person to answer incriminating questions, when there was good reason for suspecting that person had violated the law. As Macnair (1990: 67) stated, up until at least the revolution of 1688 , the common lawyers shared the same 'mental universe' of the canonists on the question of self-incrimination. Indeed, whereas English common lawyers used the Nemo tenetur prodere seipsum (no person is to be compelled to accuse himself) maxim ${ }^{12}$ to rein in the activities of the Court of High Commission or the Star Chamber, they were not seeking to establish an invariable rule of practice or 'procedures indispensable to fair trial or due process of law' (Levy, 1968:321). Had this been their aim, they would have applied the rule to unsworn statements made in their own courts, or at least they would have argued that it should be applied there. The fact is, they did not even make the connection. In practice, the accused was legally obliged to formulate a factual defence and, at the same time, to counter the prosecution's factual evidence as it unfolded. Even when the accused was provided with defence counsel around the middle of the eighteenth century, the counsel's role was strictly limited to advice on legal issues, never on factual matters (Beattie, 1991). The underlying assumption was that innocent defendants could easily persuade the jury of their innocence. In contrast, guilty defendants would betray themselves to the jury through speech, gesture, demeanour, and manner (Langbein, 1994:1053). Accordingly, seventeenth and eighteenth century English courts frequently drew adverse inferences from the accused's tactical use of

${ }^{11}$ According to Langbein (2004: 99), whereas the Europeans had turned to Romancanon law of proof in order to legitimate a system of adjudication by professional judges, in England, the ordeals were replaced by trial jury which was assembled from men living near the scene of the crime. Given the fact that the English accepted 'the rough verdict of the countryside, without caring to investigate the logical process' (Pollock and Maitland, 1898, 660-661), the use of abusive interrogation practices to obtain confessions was indeed much less prevalent in England than it was on the Continent.

${ }^{12}$ The recent Helmholz-Macnair canon law theory suggests that the maxim Nemo tenetur prodere seipsum originated within the ius commune as a defensive sub-principle of inquisitorial procedure centuries before its appearance within the common law. The idea was taken up by seventeenth century common lawyers and expanded into the modern format (Helmholz, 1990:967; Macnair, 1990:70). 
silence, seeing it either as directly or indirectly inferring guilt in order to build a prima facie case (Theophilopoulos, 2003:162).

\subsection{Morden Age: Individual Autonomy and the Right to Remain Silent}

The turning point of European legal civilization came in the sixteenth and seventeenth centuries with the emergence of the theories of Copernicus (14731543), Kepler (1571-1630), Galileo (1564-1642), and Newton (1642-1727) about the nature of the physical world. These new theories reduced the earth to a mere part in the universe, a planet occupying an immense space, and suggested that individuals could make their own inquiries into the nature of the world. This view came to be reflected in the writings of philosophers as diverse as Descartes (1596-1650), Spinoza (1632-1677), Leibniz (1646-1716), Rousseau (1712-1778), Bacon (1561-1626), and Locke (1632-1704). Whatever their differences, these philosophers all came to agree that knowledge may be gained by anyone working on his own, rather than by appeal to authoritative propositions (Jackson, 1988), a doctrine that has been called the 'principle of universal cognitive competence' (Cohen, 1983:1). It actually took some time for European procedure, which had been strictly based on ius commune, to adopt the spirit of universal cognitive competence. By the eighteenth century, a number of writers imbued with Enlightenment thought began to mount a collective attack on the whole system of legal proofs. Beccaria, for instance, developed as a replacement for the system of legal proofs a system of moral proofs by which the weight of evidence was to be assessed not by the sheer number of proofs but by the number of independent items of evidence that could be obtained (Esmein, Mittermaier, and Garraud, 2010:364). However, the procedural reforms did not begin until 1808, when the great Napoleonic Code d'instruction criminelle caused the biggest shakeup of European criminal justice machinery since the decision of the Fourth Lateran Council of 1215 to abandon the old system of trials by ordeal ${ }^{13}$ (Summers, 2007).

The key features of the reformed European procedure as it first emerged in France and later in other European countries was the abolition of the system of legal proofs and the establishment of the doctrine that the accused cannot lawfully be required to answer incriminating questions or confess during interrogation. More precisely, on the Continent, the examining magistrate, and trial judge were no longer fettered by the doctrine of 'two eyewitnesses or confession'. Instead, they were free to conduct an active investigation of the

${ }^{13}$ The 1808 Code provided for the separation of the roles of the prosecutor and the investigating judge. As a result, out went the pure inquisitorial system whereby the same authority, an examining judge, was responsible for prosecuting, examining, and judging and in came a separation of the roles of judging and prosecuting (Summers, 2007:34-35). 
truth and evaluate the evidence according to their convictions (Jackson, 1988, 553-555). Similarly, across the channel in England, the rather vague and shifting standard of proof was replaced by a new 'beyond reasonable doubt' standard by the late eighteenth century (McCormick, 1954). The idea that the accused was to be regarded as innocent until sufficient evidence proved otherwise gained momentum. Given that evidence introduced at a trial was subject to the free evaluation of the judge or jury, it became clear that confessions obtained by the threat or use of physical and psychological force were not voluntary and tended to be unreliable (Pieck, 1962). Meanwhile, in the wake of the Enlightenment and the French Revolution, there was increasing consensus, both in England and on the Continent, that the government should not be permitted to employ certain kinds of coercive pressure against any individual, regardless of the individual's guilt or innocence (White, 2001:2-3). Consequently, animated by both scepticism as to a coerced statement's reliability and concern for protecting individual dignity, European courts eventually prohibited the use of coercion and inhumane practices, including compulsion by legal mandate, ${ }^{14}$ to force an accused person to answer questions in the criminal process (Esmein, Mittermaier, and Garraud, 2010).

Despite Europeans' general recognition of the right of the accused to remain silent and its rule against the use of coercion to compel a person to answer incriminating questions during criminal proceedings, there was less agreement among the states regarding how far, short of the forgoing coercive devices, authorities could go to persuade or encourage the accused to speak, either during pre-trial questioning or during the trial. In fact, as the respublica christiana in Europe collapsed in the sixteenth century, law as the product of a sovereign legislator gradually replaced the medieval and early-modern notion of the ruler as the administrator of law, based on the conception of law as principally a matter of universal reason (Nelken and Feest, 2001:104). Therefore, one can discern a great emphasis in the English common-law system on respecting an accused's autonomous right to decide whether and how to participate in defending himself, while the Continental civilian systems put greater emphasis on a more 'social' approach which obliges states to take positive action to protect the rights of the accused (Trechsel and Summers, 2005:263-264). This difference in approach would seem to be reflected in the different political ideologies underpinning the two systems-classical laissez faire versus amore paternalist approach (Damaska, 2005). Thus, the English system has tended to put a high premium on the accused's autonomous decision to admit, deny, or refuse to answer in the face of potentially incriminating questioning. Under British law, police are required to warn a person of his or her right to silence and to counsel prior to interrogation when there are reasonable grounds to suspect the person

${ }^{14}$ As a general rule, suspects are not prosecuted for refusing to answer questions before trial and are never prosecuted for contempt for failing to testify at trial (Jackson, 2009). 
of an offense, ${ }^{15}$ again upon arrest, ${ }^{16}$ and, finally, when a detained person is charged or informed that he or she may be prosecuted for an offense. ${ }^{17}$ Once a suspect requests legal advice, the police cannot continue to question him until he has consulted with a solicitor, ${ }^{18}$ and the suspect must be allowed to have the solicitor present whenever he is interviewed if the solicitor is available. ${ }^{19}$ Damaska (1973: 587) observed, 'The Anglo-American adversary system's commitment to values rather than the pursuit of truth has caused it to erect higher evidentiary barriers than its Continental non-adversary counterpart'. In contrast, Continental civilian systems have given less opportunity to accused persons to exercise choice over the course of procedural actions, because there is a general understanding in civilian systems that rules implementing the right to silence should not present substantial barriers to testimonial evidence from the accused (Van Kessel, 1998:842). This perspective is reflected in the limited right to counsel during initial periods of police interrogation and in the 'permissive approach' to waiver rules that allow continued questioning in the face of assertions of silence or expressions of a desire for counsel (Van Kessel, 1998; Ma, 2007). Not surprisingly, the reality in most Continental jurisdictions is that most suspects do speak or testify during pre-trial questioning by the police or the investigating magistrate (Jackson, 2009:848).

Some see in this difference of approach a fundamental dichotomy between English common-law and Continental civil-law systems. It may be better, however, to view it in terms of competing tendencies within common-law and civil law systems, one emphasizing individual autonomy, and the other, accurate outcomes. To take two examples, despite the traditional emphasis in inquisitorial systems on the importance of truth-finding, Continental countries have seen a growth in administering warnings to suspects about their right to remain silent prior to interrogation and the use of an exclusionary rule to ensure police compliance with the warning requirement ${ }^{20}(\mathrm{Ma}, 2007)$. However, a

15 The Code of Practice for the Detention, Treatment and Questioning of Persons by Police Officers (Code C), § 10.1 .

${ }^{16}$ Ibid. § 10.3 .

17 Ibid. $\$ 16.2$.

${ }^{18}$ Ibid. $§ 6.6$.

${ }^{19}$ Ibid. $§ 6.8$.

${ }^{20}$ Notably, forty-five years ago, when the U.S. Supreme Court in Miranda v. Arizona (1966) held that the Fifth Amendment privilege against self-incrimination applied to the pretrial interrogation of suspects in custody, few European countries required the police to issue preinterrogation warnings. Except for coerced confessions, it was also rare for European courts to exclude evidence for police failure to follow procedure rules $(\mathrm{Ma}, 2007,6)$. The U.S. Court then seemed to lead the way in expanding the procedural safeguards for suspects subject to police inquiry. Nevertheless, in the post-Miranda cases, to accommodate the conflicting interests between law enforcement and individual interests in police interrogation cases, the U.S. Court has carved various exceptions out of Miranda exclusion policy, for instance, the public 
counter-tendency in English common-law jurisdiction is seen in the shift from giving more procedural safeguards in police questioning and thus away from an emphasis on respect for autonomy. The modification to British law in 1994 that curtails the right to silence and permits the courts to draw adverse inferences from a suspect's failure to answer police questions ${ }^{21}$ clearly exemplifies crime control concerns (O’Reilly, 1997).

This gradual 'convergence' in the interrogation procedure of common and civil law systems in Europe is also because that there have been external pressures on states to adopt common procedural standards in police questioning. Since it came into force in 1953, the European Convention on Human Rights (ECHR) has served as a reflection of Europe's effort toward the establishment of common standards of individual human rights and freedoms. The forty-seven countries that are currently signatories to the Convention are subject to the jurisdiction of the European Court of Human Rights (ECtHR), which was established in 1959 in Strasbourg as a mechanism to interpret and enforce the obligations created by the Convention. In addition, supranational institutions, such as the Council of Europe and the European Union ${ }^{22}$, provide a vehicle for strengthening cooperation within a framework of common procedural rights and guarantees laid down by the ECHR and, more recently, the EU Charter of Rights (Cape, Namoradze, Smith, and Spronken, 2010).

In its interpretation of fair interrogation standards, the European Court of Human Rights has given weight to both autonomy rights and the notion of effective defence to achieve accurate outcomes in fact-finding. Although the Convention contains no explicit reference to the right to remain silent and the

security exception, which permits the police to interrogate a suspect without the Miranda warning if there is evidence indicating that immediate interrogation is necessary for some urgent public need (Ma, 2007; Roth, 2008).

${ }^{21}$ According to the Police and Criminal Evidence Act 1984 (PACE 1984), silence during police questioning should not lead to adverse comment by either the judge or the prosecution. In particular, the judge was not permitted to suggest to the jury that silence or a refusal to answer questions was in any way evidence of guilt (Zander, 1990:144). However, a modification was made by the Criminal Justice and Public Order Act 1994 (CJPOA).

${ }^{22}$ Article $82 \S 2$ of the Lisbon Treaty provides for the establishment of minimum rules in respect of, inter alia, the rights of individuals in criminal procedure. Further, on 1 July, 2009, the Swedish Presidency presented a Roadmap for Strengthening Procedural Rights of Suspected or Accused Persons in Criminal Proceedings. The Roadmap was incorporated into the Stockholm Programme for the period 20102014, which was adopted by the European Council on 10/11 December, 2009. The Roadmap, which provides for a step-by-step approach, identifies six areas that future EU work should focus on. Specifically, Measure C of the Roadmap, which is mainly concerned with the right to a legal counsel at the earliest appropriate stage of criminal proceedings, is due to be legislated in 2011. 
privilege against self-incrimination, the Court, drawing its rationale from Article 6 of the Convention, has been steadily developing its distinctive vision of the right and privilege ( $\mathrm{Wu}, 2011)$. The Court's perspective suggests that, as a rule, access to a lawyer should be provided at the first interrogation of a suspect by the police. Somewhat akin to the Miranda rules ${ }^{23}$, when a suspect has invoked the right to be assisted by counsel during interrogation, the Court is of the opinion that the suspect should not be subject to further interrogation by the authorities until counsel has been made available to the suspect, unless the suspect himself initiates further communication, exchanges, or conversations with the police or prosecution ${ }^{24}$. In Salduz, the Court expressly linked the right of access not only to the need to protect the accused against abusive conduct on the part of the authorities and the prevention of miscarriages of justice but also to the fulfilment of the aims of Article 6, notably 'equality of arms between the investigating or prosecuting authorities and the accused' 25 . Although, traditionally, the principle of equality of arms has been reserved for the trial, the realization that the examination of evidence does not always occur in court has become widespread (Summers, 2007:28). Moreover, the situation in the interrogation room is compounded by the fact that suspects normally want to provide an account of themselves (Jackson, 2009:850). In the Court's view, the defence right to speak for oneself is a double-edged sword with the potential to count against the suspect. In Pishchalnikov, the Court reiterated that criminal law-substantive as well as procedural-and criminal proceedings are a rather complex and technical matter that is often incomprehensible to laypersons, including the suspect. ${ }^{26}$ In the absence of assistance by counsel, who could provide legal advice and technical skills, the applicant is unable to make the correct assessment of the consequences the decision to provide an account or confess would have on the outcome of the criminal case. ${ }^{27}$ Importantly, practically at every stage of criminal proceedings, decisions have to be made, and the wrong

${ }^{23}$ The Miranda Court established a general rule that once a suspect indicates that he or she does not wish to be interrogated, the police must cease all questioning (Van Kessel, 1998). With respect to whether the police may make attempts to obtain a waiver of the right to remain silent from a suspect, the U.S. Court in subsequent decisions made a distinction between the situation when a suspect asserts his or her right to remain silent and the situation when the right to counsel is invoked (Ma, 2007). If a suspect asserts only the right to remain silent, the police may resume questioning after a substantial time lapse so long as they properly advise the suspect of the Miranda rights prior to interrogation (Michigan v. Mosley, 1975). But once a suspect has invoked the right to counsel under Miranda, there can be no further interrogation until counsel has been made available unless defendant initiates further communications with police officers (Edwards v. Arizona, 1981; Arizona v. Roberson, 1988; Minnick v. Mississippi, 1990).

${ }^{24}$ ECtHR 24 December 2009, Pishchalnikov v. Russia, (no. 7025/04), § 79.

${ }^{25}$ ECtHR 27 November 2008, Salduz v. Turkey (no. 36391/02), § 53.

${ }^{26}$ ECtHR 24 December 2009, Pishchalnikov v. Russia (no. 7025/04), § 84.

${ }^{27}$ Ibid. $\S 85$. 
decision may cause irreparable damage. The Court then concluded that reliable knowledge of law and practice is usually required to assess the consequences of such decisions. ${ }^{28}$ A lawyer can not only ensure the legality of any measures taken in the course of the investigation proceedings; he can also provide advice and assistance on how to mount the most effective defence. For sure, various options are available at this stage as they are at the trial (Wu, 2011:54). As Jackson (2009: 861) pointed out, 'once the rights of the defence are put in place ... the right of silence reverts to an exercise of will or choice on the part of the individual accused, but a choice that is made on an informed basis as part of a defence strategy which is taken in full recognition of the costs and benefits of its exercise'.

\section{The Evolution of Criminal Interrogation Rules in China}

The European case provides a particularly valuable contrast to the Chinese one.

\subsection{Legalistic Bureaucracy to Enforce Confucian Norms and Moral Domination in Imperial China}

The Zhou dynasty (1046-256 B.C.) maintained fairly effective control of China for a few generations, but then gradually lost its grip. After 770 B.C., real power was divided among a number of states. During the war period, the Qin State's minister, Lord Shang (390-338 B.C.), overhauled the state according to legalistic ideas. His legalism-inspired reforms deployed a detailed penal code through an elaborate, tightly controlled bureaucracy to ensure efficient control in the hands of the ruler (Bary, 1995). These reforms, together with other favoured agricultural policies, successfully bolstered the state's power. Finally, the Qin state unified China and established the Qin Empire (221-206 B.C.). Although the ruthless rule of the Qin led to the empire's speedy downfall, the succeeding Han dynasty's emperors, facing tremendous pressure to consolidate their rule in such a large territory, retained the Qin's essentially legalist apparatus for central administration (Windrow, 2006).

At that time, the Confucian intelligentsia also started to explore the relationship between Confucian $l i$ and legalist $f a$. In a similar thought shift, Dong Zongshu (179-104 B.C.), a Han Confucian, integrated the legalist and Yin-Yang school of thought to create his own Confucian doctrines. He overhauled the standard interpretation of the Confucian classics and advocated combining the functions of $l i$ and $f a$ by emphasizing the supremacy of $l i$ and the subservience of fa. On the presumption of the operations of Yin (阴) and Yang (阳), he further

${ }^{28}$ Ibid. $\S 84$. 
emphasized the emperor's sacrosanct power in governing the state and in enacting laws. Simply put, this shift in Confucian thought legitimized the use of bureaucracy, recognized the role of law and punishment, and helped to uphold the superiority of the emperor (Ma, 1987). Eventually, Emperor Wu (157-87 B.C.) adopted Confucianism as the official orthodox doctrine. Confucian moral standards then began to become part of the content of law, and criminal code became the instrument for executing such content. Even after the Han dynasty's fall in 220, successive dynasties continued to accelerate the Confucianization of the legal code. Perhaps most importantly, the Tang Code, ${ }^{29}$ first issued in 637 and last revised in 737 during the Tang dynasty (618-907), represents the final synthesis of the legalist and Confucian ideals, which had begun to merge centuries before (Ma, 1987: 673).

The 'legalization of Confucianism' process was further fostered by the internal bureaucratic shifts in imperial administrations. After the Han dynasty, the Chinese government began to operate through its bureaucracy, brimming with educated officials who had passed state examinations based on Confucian Classics. The Confucian concept of family was in fact extended to judicial and governmental affairs, where the district magistrate was called the 'parent officer' (fu-mu guan, 父母官) and evidenced presumably virtuous moral characteristics, such as benevolence, impartiality, and superior wisdom (Alford, 1984). As Ren (1997: 25) put it, 'the government was not a public servant body, but a sacrosanct paternity'. Using persuasion rather than force, the Confucian ruler was supposed to inspire others to become humane and rule by virtue of his moral vision (Peerenboom, 2002:32-33). Scholar-bureaucrats formed the main ruling class of China up until the nineteenth century (Moise, 1994; Windrow, 2006).

\subsection{The Tang Code: Moral Persuasion, Confession, and Coercion}

As indicated, the Tang Code is characterized by Confucian moral standards (li) and its penal attribute ( $f a$ ). The Code's preamble states that the primary aim of the law is to maintain human order in coordination with the cosmic order of Heaven and Earth. In other words, the ruler's remedial use of law serves to redress human disorders and restore the proper balance between man and nature. Hence, if a crime occurs, the truth has to be discerned so that the state can administer appropriate punishment ${ }^{30}$ and restore social harmony (Ren, 1997, 31). Because of this assumption, determining factual guilt, which requires the

${ }^{29}$ The Tang Code is the most influential legal work in imperial China. The Code served as the basis for all subsequent Chinese criminal and criminal procedure law until the foundation of the Republic of China in 1911, and some of its attributes can be seen even today(Ansley, 1986).

${ }^{30}$ Penalties in imperial China were designed to fit the criminal, not the crime (Ansley, 1986:171). 
offender's admission of guilt and repentance of the crime, is almost indispensable for concluding criminal cases before the courts (Tang Code, Art. 476). Therefore, undergirding the interrogation procedure of the Tang trial was a set of rules whose purpose was to persuade or oblige the accused to respond or confess to the charges against him.

\subsubsection{Confession by Persuasion}

The questioning of accused criminals in imperial Chinese courtrooms was designed to teach, humble, and extract contrition from wrongdoers. The structure of Chinese trial inquiries can be described as 'paternalistic's1 when historical sources allow one to see how an imperial trial was conducted. In general, a criminal case was first investigated, then prosecuted, and tried by a district magistrate who was both the judge and chief administrator of the region. At trial, both the accused and the accuser were required to kneel on the ground in front of the magistrate who was assigned the responsibility of ferreting out the truth (Gelatt, 1982:264-265). As an authority in a leading position, the magistrate could control and extend the questioning sequences, as he deems necessary to extract the desired response (Chang, 2004). In contrast, suspects were required to respond interactively to the questions asked. Though the frequent, instinctive desire of the guilty to play innocent was recognized, the Tang trial was not concerned with exposing the magistrate to the suspect's dubious statements. On the contrary, the Code provided that the magistrate should sit back at the beginning of the case and expect that evidence damaging to the suspect would come out of his altercation with the accuser and witnesses (Art. 476). It was believed that precious information could be obtained even from false denials of guilt, inconsistencies, and other verbal and non-verbal expressions emanating from the suspect $(\mathrm{Zu}, 2008)$. The Code went on to specify that both the accused and the accuser's statements should be verified to the extent feasible (Art. 476). ${ }^{32}$ Eventually, if the suspect managed to prove to the magistrate's satisfaction during the course of the interrogation that he was innocent and had been falsely accused, one way to maintain proper social

${ }^{31}$ Chinese patriarchy fundamentally differs from that found in the West. Jamieson (1921: 4) noted that there is no Chinese concept equivalent to patria potestas; in Chinese the relevant concept identifying patriarchy is xiao (孝). More specifically, Patria potestas defines jurisdictions within which a person can exercise personal discretion, and accordingly defines relations of authority between people. Xiao defines roles, actions and values that accompany the roles, and, accordingly, a person's duty to a role. These two concepts imply different ideas about the nature of patriarchal domination both within and especially beyond the family (Hamilton, 1984:411).

32 Thus, for example, if a suspect confessed to a murder, he should have been asked where he put the weapon. If he said he threw it into the river, the magistrate was supposed to send someone to find it, so that once fetched, it could corroborate the confession. 
harmony was to punish the accuser for the crime of false accusation (Bodde and Morris, 1967:402-408). If the suspicions were confirmed, the suspect would be greatly shamed and criticized to persuade the 'offender' to change his mind, repent, and admit to the facts of the crime (Ren, 1997; Chang, 2004). Chinese literature, arts, and folklore often portray the magistrate as talking loudly, powerfully, and fiercely to urge the reluctant suspect to confess ( $\mathrm{Wu}$ and Vander Beken, 2012).

\subsubsection{Confession by Judicial Torture}

Judicial torture, at least in theory, was reserved as a last resort for those who were under strong suspicion, but continued to defy confession of their moral faults (Tang Code, Art. 476). It had been long recognized by Chinese lawmakers that the agony of torture might induce the innocent to confess things that they never did ( $\mathrm{Zu}, 2008)$. Hence, a highly detailed set of rules governing the application of torture was put forward by the Code to enhance the reliability of tortured confessions and acquit the innocent. First, torture practices were permitted only in cases where evidence strongly supported the suspect's guilt. As observed earlier, Article 476 of the Code laid down specific procedures regarding interrogation, such as the confrontation between the accused and the accuser and the co-examination of objective evidence. By and large, magistrates were not vested with discretionary powers; rather, they were required to strictly enforce the statutory rules (Alford, 1984; MacCormack, 1987). Hence, violations of these rules by magistrates carried a punishment of sixty strokes with a wooden stick (Tang Code, Art. 476). Second, magistrates needed prior approval from higher officials if they decided to employ torture (Tang Code, Art. 476). Third, the types of torture were limited to whipping or beating with a bamboo strip or wooden stick, and adjusted depending on the suspect's responses during the examination. The Code provided that torture should not exceed three applications with intervals of 20 days between them; the number of whippings or beatings should not exceed 200 in total. If the suspect refused to confess even after these beatings, he should be released subject to obtaining a guarantor pending the trial (Tang Code, Art. 477). Presumably, 20 days was considered a reasonable period for individuals to 'reflect on' their acts and choose to repent or confess. This can be seen as another example of lawmakers' intent to deter undesirable social behaviour and change the wrongdoer's mind.

\subsubsection{Factual Guilt, Shaming and Obligations of Roles}

All this clearly implies that the essential purpose of the criminal interrogation at the Tang trial was not determining legal guilt of a crime by using legally admissible statements against the accused, but, rather, discovering factual guilt through the offender's confession and through making the wrongdoer morally shameful and remorseful. Judicial torture, which, together with the confession 
reward policy, ${ }^{33}$ was lenient to those who complied with the government, fortified the wrongdoer's deference to legal authority.

Moreover, power restriction in the imperial Chinese courtroom apparently was not found in the allocation of rights and duties through a system of general norms, as in the West, but in the maintaining of the proper relationships among those who held different 'roles'. In medieval Europe, as discussed earlier, each individual seeks his own salvation, in a secular as well as a religious sense. As a result, Western law preserved the personal sphere by institutionalizing rights and obligations of individuals. In contrast, the Chinese, with no transcendental sources of legitimation and under the strong influence of Confucian thought, built their legal system on assumptions of harmony among hierarchically arranged players. Individuality was defined in terms of one's responsibility to explicitly defined roles. More specifically, the suspect, as a subordinate member of the family, had the obligation to be obedient and admit his moral guilt. The judge or magistrate, as the head of a family, had the authority and obligation to persuade the suspect to change his mind and confess based on evidence and patience. Hence, in theory, power is impersonal, non-intentional, and directed towards maintaining the harmony of the whole. It is actually the duty of all individuals to conform to their roles in order to maintain social harmony. Accordingly, 'giving each his due' is not emphasized in the Chinese legal culture.

\subsection{A Stable Interrogation Model for Centuries}

Through the interplay between Confucian moral standards and legalistic bureaucracy, the 'persuasive' interrogation model of the Tang Code proved astoundingly stable by thriving until the early twentieth century.

On the one hand, rather than simply enforcing an arbitrary set of government-defined criminal procedures, the interrogation rules noticeably reflected social norms which were already pervasive, providing legal enforcement with powerful social legitimacy. In fact, after Confucianism became the official orthodox doctrine in China, families who were affluent enough to practice it engaged private tutors to teach their children Confucianism. Schoolboys were required to learn the entire Analects by heart (Grant, 1989). Among poor families, Confucianism was passed on by parents or other adults from generation to generation (Jiang, Lambert, and Wang, 2007). Therefore, there is good reason to believe that Confucian moral standards, particularly those dealing with contrition, patriarchal relationships and familial obligations, were to some extent internalized within Chinese citizens. Meanwhile, as observed earlier, Confucian doctrines have, since the Han dynasty, served as the

${ }^{33}$ The Tang Code provided detailed statutory clarifications of penalty reduction or remission for offenders who confessed or surrendered voluntarily according to the seriousness of their offences (Rickett, 1971; Ren, 1997). 
guiding light to define what might or might not become a matter of law and govern the administration of criminal penalties. The consensus between law and morality often indicates that what the state seeks to enforce by compulsion corresponds largely to the sense of right and wrong of the society in general (Ren, 1997). In the West, as Connery (1955: 181) revealed, moralists maintain that no criminal is obligated to spontaneously reveal his crime to the public authorities. This would be expecting too much of human nature. In contrast, the Confucian Chinese regarded admitting one's misconduct in public and desiring to change oneself as valuable virtues (Lu and Miethe, 2003; Fung, 2006). Judicial torture in imperial China thus is not so much a legal tool, as it was in medieval Europe, to extract information and statements necessary for a legitimate conviction, but rather an extreme case in which law and morality become onewhat Confucianism morality 'forbids', the law 'punishes'.

On the other hand, perhaps more importantly, this 'persuasive' interrogation model could survive over a millennium in imperial China, not only because social consensus unified law and morality, but also because of the model's inherent connection with increased imperial hierarchical powers. As already suggested, Confucian codes of morality (li) such as xiao (filial piety, 孝) and family loyalty were enforced by legalistic $(f a)$ reward and punishment machineries. In this way, the throne, through unrelenting fortification of familial and social hierarchies, transformed the family into a de facto extension of the bureaucratic state (Windrow, 2006). Indeed, members of society that held relative power in informal positions, such as father and brother, had an interest in maintaining the social order through the mediation of conflicts, because the restoration of order granted them power and prestige over their subordinates. Moreover, imperial law unequivocally gave parents extended rights, ranging from the right to punish children physically to the right to command their child's suicide for moral reasons (Ren, 1997:27). The result in theory, and to a remarkable degree in practice, was a system designed to educate wrongdoers in a subtly graded way, which began with the minor 'punishment' fathers used to force their children to confess and recognize moral faults. It then increased to still minor but sometimes different devices available to intervening authorities, and finally climaxed with the potential application of more severe torture inflicted by formal legal authorities. This complex gradation ensured that informal, socially-based enforcement of social norms occurred continually and finally fortified people's deference to authorities, leading ultimately to consolidation of power in the hands of the throne. Under this social structure, district magistrates, members of the real ruling class of society, could maintain their enormous power and authority in courtrooms. In contrast, criminal suspects were put in a disadvantageous position both interactively and socioculturally. Hence, magistrates, as interrogators, could fully exercise their interactive power to humiliate and attack suspected criminals' moral sense, or even torture them, to elicit confession and remorse. 


\subsection{Legal Changes in Late Imperial China}

Under the Tang (618-907) and Song (960-1279) dynasties, China was among the leading cultures of the world, far superior to Europe in wealth, technology and science (Moise, 1994). However, by the time of the Ming dynasty (13681644), China had gradually fallen into decline. By the middle of the nineteenth century, the continuous isolationist policy adopted by the Qing dynasty (16441911) was beginning to break down in the face of European military threats. After several failures to resist foreign military attacks, especially the failure of the Boxer Uprising in 1900, Empress Dowager Cixi (1835-1908) finally accepted the necessity of changing the mode of governance in accordance with the changing circumstances to stay in power. Hence, new policies (xinzheng, 新政) were initiated, including the revision of the legal system. In 1904, further spurred by foreign pressures and high-ranking officials, the Bureau of Legal Codification was established to draft a new series of codes, including criminal and criminal procedure law. Shen Jiaben (1840-1913), the co-director of the Bureau, combining Confucian ethical norms with German and Japanese models of punishment and due process, hoped to revive the ideal of a benevolent government (renzheng, 仁政) that punished lightly (xingqing, 刑轻) and forbade extracting confessions through torture (Dikötter, 2002). It was due to efforts of Shen and his colleagues that the government put into effect the 'New Penal Code of the Great Qing' in January 1911. In this legal document, corporal punishment and extracting confessions by torture were outlawed. Although some legalists considered this code 'conservative' and numerous articles argued for the preservation of the Confucian legal tradition, the dominant view still seems to be that it is an important landmark in China's legal modernization (Wang, 1997). However, the first wave of legal modernization could not take root during the turbulent period following the Qing dynasty's collapse.

\subsection{The Mao Era: the 'Lawless' State and Traditional Legal Culture}

Chinese Communists often claimed establishment of the PRC in 1949 was a total break with China's 'feudal' past (Gelatt, 1982). Replacing Confucianism, Marxism-Leninism became the official orthodoxy guiding social transformations and governing other facets of national affairs. Notably, Marxism has a poor opinion of law. Marxists argue that the capitalist law is nothing more than a suppressive tool, which traditionally served the interests of a wealthy minority. When a proletarian revolution succeeds, the state gradually withers away and law will not be needed (Engels, 1979:164). In the interim, law serves to advance the socialist revolution towards communism and maintain the socialist order. More precisely, 'law is to be used by the proletariat as a weapon in class struggles against the enemy in order to realize the people's democratic dictatorship' (Peerenboom, 2002:44). Owing to the dominance of a heavily 
instrumental understanding of law in the Mao era, the legal restraints on the power of police in criminal interrogations varied in accordance with the changes in the official attitude towards law and depended largely on the political mode towards class struggles ( $\mathrm{Wu}$ and Vander Beken, 2012). Free of substantial restraints, the aspiration of the investigator to capture the suspect as a testimonial resource is perfectly 'understandable'. The suspect is, after all, the most efficient possible witness in the investigator's eyes (Cui, 2003). Consequently, there have been frequent reports of brutality in interrogations that clearly amount to cruel, inhuman, and degrading treatment, and sometimes even 'torture' under contemporary international law (Chen, 2000).

At this point, one question arises. No doubt, this type of law enforcement must exercise a great deal of discretion so that its key players can manipulate the interrogation procedure to meet practical needs. To understand this issue, one should not overlook the influence of the traditional Chinese legal culture, which enhanced rulers' real and symbolic status as the locus of political authority. Although, literally, Marxism has little in common with the Chinese tradition, the influence of Confucianism and legalist values remained a strong driving force in Communist China even though this was not officially recognized (Ren 1997; Peerenboom, 2002).

In the process of building a new elite power structure, the Communists departed from the imperial thrones that had stressed family loyalty by displaying higher loyalty to the state. During the early decades of the socialist construction, the informal social control preferred by Confucianism was largely institutionalized through an urban household registration system, which linked individuals' residency with their entitlement to social programs. The strict control of population mobility effectuated different social control mechanisms in community, which were primarily responsible for handling local disputes and wrongdoers who had committed minor offences (Whyte and Parish, 1984). When individuals violated rules under the Security Administration Punishment Act $^{34}$ the police had the authority to impose a series of administrative sanctions without formal litigation. Notably, the formal court process was reserved only for offenders who committed serious crimes, especially the so-called class enemies who did not accept and support the Communist leadership (Rojek, 1985). In this manner, the Communist leaders enforced stratifications within the civil society between those who supported the socialist state and those who did not, and thus created a web of status and privilege in the criminal justice sphere to bolster their own legitimacy. Under this arrangement, traditional shaming, moral control, and mutual checks were, to some extent, as effective as in previous eras (Rojek, 1985; Lu and Drass, 2002). As a result, in the interrogational rooms, the questioners (i.e. the police, the procuratorate, and the judge), who were both the representatives of the state power and 'moral

${ }^{34}$ Promulgated in October 1957. 
executors', enjoyed enormous authority. The justice officials generally had a strong sense of responsibility and moral consciousness to persuade suspects to confess (Ren, 1997:130). On the contrary, suspects, as in imperial times, were still in a socio-culturally disadvantageous position. They were supposed to be obedient and cooperate totally 35 in the questioning (Ren, 1997:119-122). Nevertheless, just as laws do not create a lawful society, morals do not create a moral order. The striking contrast in power between the two status groups also gave the law enforcement great space for manipulation. Therefore, it is not difficult to understand why 'voluntary' cooperation and confession in judicial questioning during that 'lawless' period may not have been voluntary at all.

\subsection{The Reform Era: 'Modern' Legal Rules and Answering Questions Truthfully}

Upon Mao's death and the subsequent political downfall of the 'Gang of Four' in 1976, the CCP's devotion to the political struggle against class enemies faded away. The new CCP leadership quickly launched the modernization programme which was summarized as the 'Four Modernizations'modernization of agriculture, industry, national defence, and science and technology (Moise, 1994:194). In the meantime, many Party leaders, having suffered personally and severely during the lawless period of the Cultural Revolution, were eager to advocate greater reliance on the law as a means of preventing the recurrence of such policy-driven excesses. In addition, strengthening the legal system was also considered essential to win back legitimacy both at home and abroad and to provide an orderly environment for economic development (Peerenboom, 2002:55).

Since then, the new leadership in China has made rapid progress on the legislative front. Notably, the first step it took after the ten-year turbulence was the promulgation of criminal law and criminal procedure law (CPL) in 1979. The promulgation of these two laws no doubt marked the beginning of the redevelopment of China's criminal justice system (Leng, 1982). Despite remarkable progress, legal scholars and criminal justice practitioners noted various deficiencies in the 1979 CPL in the ensuing years (Ma, 2003). Specifically, there was broad consensus that the law still marginalized the rights of the suspect $(\mathrm{Fu}, 1998)$. In an effort to progress towards judicial democratization and fairness, China revised the 1979 CPL in 1996.

35 The suspect's deference to legal authority was further fostered by the official slogan of 'leniency to those who confess their crimes and severity to those who refuse to' (Bao and Chelminski, 1973: 33). 


\subsubsection{The Criminal Interrogation Rules under the 1996 CPL}

Structures and concepts influenced by the West had already undoubtedly found their way into Chinese legislation. Nevertheless, the drafting of legal texts was always influenced by historical experiences from which the texts were derived and viewed in light of the rationale behind their application. The 1996 CPL is no exception. In general, the content of the 1996 CPL is in no way similar to that of the old imperial codes. However, if one compares the central features of contemporary interrogation procedure with those of the 'persuasive' imperial type, it is apparent that many ideas are common to both. The current questioning procedure still seems to focus on objective fact-finding and to similarly persuade the suspect to respond to the incriminating evidence against him, thereby fostering a high level of self-incriminating statements or confessions.

\subsubsection{Proper Preparation Prior to the Initial Interrogation}

Under the $1996 \mathrm{CPL}$, the police are given power to interrogate a suspect under two types of situations:

(1) The police may interrogate a suspect after he/she is detained or arrested and taken into police custody (1996 CPL, Art. 65, 72); and

(2) The police may summon a suspect, who need not be detained or arrested, to a designated place in the city or county where he/she stays for interrogation, or the suspect may be interrogated at his/her residence (1996 CPL, Art. 92).

These clauses definitely do not imply that, whenever a crime happens, the police have the power to interrogate whomever they please. In the first situation, after a suspect is detained in the detention house, as a typical investigatory act during criminal investigation, the police may interrogate the suspect. In the second situation, the police officer in charge, who must be at or above the county level, shall determine the necessity of questioning. ${ }^{36}$ In essence, the revised CPL endeavours to limit the initial police investigation to sources of objective information other than potentially guilty parties. Nonetheless, this does not imply that it minimized the consideration of the suspect as an important source of testimonial evidence overall ( $\mathrm{Zhu}, 2006: 15-16)$. The revised law arguably devotes considerable attention to the interrogation preconditions in order to make the questioning effective and productive. There is clearly a strong emphasis on proper preparation prior to interviews. The law states explicitly that, before the interrogation, the investigator should acquaint himself with the

\footnotetext{
${ }^{36}$ Ministry of Public Security: Regulation on the Procedures of Handling Criminal Cases by Public Security Agencies (Article 173).
} 
case and its supporting evidence, and then plan and outline the questioning process. $^{37}$

\subsubsection{Persuasion based on Listening and Evidence}

During the interrogation, without the aid of a counsel, ${ }^{38}$ a suspect is expected to answer questions asked by investigators truthfully and can refuse to respond to only those questions that are irrelevant to the case (1996 CPL, Art. 93). In addition, the law pays special attention to the types of questions that need to be asked sequentially during the questioning. According to Article 93 of the 1996 $\mathrm{CPL}$, 'when interrogating a suspect, the investigators shall first ask the suspect whether or not he has committed any criminal act, and let him state the circumstances of his guilt or explain his innocence; then they may ask him questions'. Under this arrangement, the police, as the imperial magistrates, may sit back at the beginning and hope that damaging evidence will arise if a guilty suspect's concocted story crumbles upon subsequent disclosure of evidence. Such damaging evidence may arise in the form of inconsistency in the account given by the suspect, thereby demonstrating the lies told by the suspect, or in the form of failure to answer the questions posed by the police. All this evidence could be used either to encourage suspects to confess or against them at their trials (Wei, 2003).

\subsubsection{No Real Change of the Criminal Interrogation Rules under the 2012 CPL}

On 14 March 2012, the National People's Congress (NPC), China's parliament, adopted the revision to the Criminal Procedure Law at the closing meeting of its annual session. Although the new CPL (2012 CPL), which takes effect on 1 January 2013, highlights the principle of protecting human rights in the criminal proceedings (Art. 2), the law continues to emphasize the importance of being honest in police interrogation ${ }^{39}$. The new amendment is intended to further protect the suspect's defence rights and other procedural rights (2012 CPL, Art. 14), and it doubtless does so to some extent. According to Article 37 of

\footnotetext{
${ }^{37}$ Ibid. Article 178.

${ }^{38}$ Compared to the 1979 CPL, the 1996 CPL improved the rights of the suspect in various ways, but did not include the right to have a lawyer during police questioning. Only after the first interrogation or from the day on which compulsory measures are adopted does the suspect have the right to see his attorney (1996 CPL, Art. 96).

${ }^{39} \mathrm{Li}$ Zhaoxing, spokesman for the Fifth Session of the 11th NPC, said that the amendment to the Criminal Procedure Law ... 'highlights the principle of protecting human rights and punishing criminals as a whole'. http://news.xinhuanet.com/english/china/2012-03/04/c 131445010.htm (last visited July 31 2012).
} 
the $2012 \mathrm{CPL}$, the defense lawyer ${ }^{40}$ should be granted access to his detained client within 48 hours after the request for meeting is made and all the lawyersuspect meetings must not be monitored. In the chapter on evidence (2012 CPL, Chapter V Evidence), the law states explicitly that no one can be forced to prove his own guilt (Art. 50), while provisions on how to rule out illegally obtained evidence have been added (Art. 54, 55, 56, 57, 58). Nevertheless, notably, Article 118 of the 2012 CPL still provides that 'the criminal suspect shall answer the investigators' questions truthfully'. Furthermore, a new paragraph is added as Paragraph 2 to Article 118, which reads: 'when interrogating criminal suspects, investigators shall inform the criminal suspect of the legal provisions allowing for leniency for those who truthfully confess their crimes'. Seen in this way, the defense lawyer's role and other procedural safeguards within the Chinese interrogational procedure serve to demonstrate that the investigative officials adhere to the rules rather than lead to less self-incriminating statements or confessions. Eliciting reliable information and factual accounts from a person about an alleged offence is still the key purpose here. Thus it seems that the 2012 CPL hardly represents a 'real' change in Chinese interrogation rules.

\subsubsection{Law in Practice and the Limits of the Black Letter Law}

In summary, consistent with the traditional Chinese philosophy of legitimizing power in terms of one's responsibility to explicitly defined roles, the current Chinese interrogation procedure grounds the discretion of the police in criminal interrogation in terms of their role in being impartial ${ }^{41}$ and professional in truth-finding. Accordingly, unlike in Europe, where the suspect's actions in criminal questioning are institutionally structured by the jurisdictional parameters of his ability to exercise his autonomy, in China, the suspect's behaviour is restricted by the pertinent relationships that demand obedience, or honesty, during the questioning process. This interrogation model is justified by the belief that it is the duty of both the police and the suspect to conform to their roles in order to eliminate ambiguity and arrive at the 'truth'.

However, such expectations do not bear out in practice. Many Chinese scholars, relying on different sources, such as interviews with present and former law enforcement officers or individual field observation, have made the alarming assertion that the problem of confessions produced by xingxun (刑讯)-

\footnotetext{
40 Article 33 of the 2012 CPL stipulates that 'during the period of criminal investigation, a criminal suspect may only retain a lawyer as a defender'.

${ }^{41}$ Though judicial torture in criminal investigations is part of the dim and dark history of Chinese criminal law, today's China, by virtue of provisions of criminal procedure and criminal law, forbids the practice wherein suspects or the accused should be forced, by actual or metaphorical 'arm-twisting', to respond to police questioning (1996 CPL, Art. 43; the Criminal Law of the People's Republic of China, Art. 247, 234, 232).
} 
physical force or psychological duress - is widespread in police questionings in China (Wu and Van der Beken, 2010). In addition, Cui (2003: 26) comments thus on the fatal effect of police coercion on the reliability of evidence: 'Although confessions elicited by xingxun are not always false, wrongful convictions, with no exception, are all because of xingxun'.

Literature on the causes of police-coerced confessions in criminal interrogations covers a wide range of topics in terms of the levels of analysis. Notably, besides loopholes or shortcomings in the law ${ }^{42}$ and the ineffective institutional mechanisms for controlling state powers, some socio-legal studies also consider the influence of traditional cultural values a reason for coerced confessions. While coerced confession is absolutely cruel, its exercise depends at almost every level on many forms of cooperation and consensus (Lin, $\mathrm{Yu}$, and Zhang, 2006; Lin, Zhao and Huang, 2006). To understand further the social and cultural background that has led to the persistence of such pernicious interrogation practices, it is evident from the foregoing discussion that one must consider the relationship between the interrogator and suspect in criminal investigations. An analysis of this relationship, at both macro and micro levels, is presented as follows.

\section{The 'Paternalistic'43 Criminal Justice System}

First, on a macro level, China is still a 'paternalistic' state in which law enforcement is likely to have the real and symbolic status as the protector of anonymous collective interests, such as public security or social stability. This engenders a tendency to ignore concrete interests of individual suspects and lose

${ }^{42}$ For example, studies demonstrate that the 1996 CPL permits lawyers' involvement at the stage of police investigation, but neither the CPL nor any supplementary regulations contain sufficient procedural safeguards to ensure that the lawyers discharge their duties properly (Fu 1998; Ma 2003). In the law, after the first time the suspect is interrogated by the police or from the date coercive measures were used on him, the suspect can retain a lawyer to offer legal advice, or to serve as his representative in the proceedings to file petitions and complaints (1996 CPL, Art. 96). However, this provision is subject to exceptions in special circumstances. If a case involves state secrets, the suspect shall obtain the approval of the investigation organ to retain a lawyer, and he shall ask for further permission to meet or correspond with his legal counsel (1996 CPL, Art. 96). In addition, the police may be present during the lawyer-suspect meetings according to the circumstance of the case and the 'necessity' (1996 CPL, Art. 96). Articles 14 and 16 of the Regulation on Lawyers' Participation in Criminal Procedure Activity issued by the Ministry of Public Security further restrains the lawyer-suspect encounter by granting the police the power to stop a lawyer's 'unlawful' conduct or even suspend a lawyer--suspect meeting on the grounds that the lawyer had violated the rules of the meeting place.

${ }^{43}$ Chinese patriarchy fundamentally differs from that found in the West. Please refer to footnote 27 . 
sight of the abuse of power by investigators within the sphere of crime and justice.

Although the CCP has made a series of mistakes since it came into power in 1949, in Peerenboom's (2002:42) view, 'the image [of the Chinese government] remains the same: the father, knowing what is best, takes care of his children'. Today, the CCP leadership largely decides what is best for Chinese society and takes ameliorative action to solve contemporary problems. In the last three decades, the state's economic policy proved to be spectacularly successful, improving the Chinese citizens' living conditions over a relatively short period while at the same time creating a high rate of long-term economic growth (Peerenboom, 2006). The Chinese government clearly understands the importance of maintaining stability, which is a prerequisite for economic growth and for the CCP's continuous legitimacy and popularity. Hence, to satisfy the practical need for more effective social control, the current Chinese criminal justice system altered the principles of law and punishment established during the Mao era in some ways and adopted Confucianism and legalist legacies in others. As in the pre-reform era, the police, without court approval, have the authority to impose administrative sanctions on individuals guilty of minor crimes and public order violations. Wrongdoers are dealt with by the criminal justice system only when serious offences are involved. Although the police's administrative power, which was once used to control urban transients, has been eliminated under the $1996 \mathrm{CPL}$, their power for detaining criminal suspects has been extended. Thus, unquestionably, compared with those of European law enforcement, Chinese police have greater authority and power over ordinary citizens (Ma, 1997).

Apart from the political agenda, another crucial factor that further reinforces the authority of the police lies in the social changes that have occurred in Chinese civil society in the reform era. Since 1978, as China moved towards a market economy, the traditional informal social control that relied on rigid household registration and employment structures has declined (Dutton, 2000). Concurrently, increased mobility has resulted in a class of "floating population" (liudongrendou, 流动人口), who are often blamed for urban problems, including the soaring crime rates. Given that transients have no attachment, commitment, or involvement in communities, using the criminal justice system to subject them to stronger formal control is deemed necessary by urban citizens to curtail crime (Lu and Drass, 2002). Moreover, as police officers, following the 'mass-line' in policing, actually live and work in certain neighbourhoods for a long time, most Chinese citizens do not view the police as a force limiting their freedom, but as a service resource they can rely on (Jiao, 2001). As a result, the formal law enforcement is shouldering more responsibility for solving crimes, thus reinforcing itself in both real and symbolic senses (Wong, 2001). 
Importantly, as a group of legal professionals, Chinese defence counsels have not been a prominent force in furthering the balance of state power. In imperial China, the status of scriveners, who were labelled 'litigation tricksters', was considered low, because the pursuit of self-interest by adverse litigation is at odds with the paramount virtue of social harmony, as it signifies one's refusal to take responsibilities for one's action ( $\mathrm{Yu}, 2002$; Clark, 2008). Under socialist China, the state belongs to the people; thus, lawyers are not expected to oppose the state in a criminal investigation but shoulder the dual responsibilities of not only protecting the rights of the suspect but also, more importantly, helping the state seek the truth (Lu and Miethe, 2002; Clark, 2008). For millennia, China had no officially recognized legal profession, which means the use of legal counsel is rather new to the Chinese criminal justice system. Until recently, more than 70 per cent of the criminal cases were processed without lawyers appearing in court on behalf of defendants (Wu, 2006a). In this context, Lu and Miethe (2002: 277) observed, 'contrary to the image of an advocate of the defendant, Chinese attorneys under the reform policies still play a major role in legitimizing the current legal system'. Chinese counsels, especially seasoned attorneys, know how to obtain the best results for their clients by not being 'combative' or 'arrogant', but instead 'deferential' and 'submissive' during criminal proceedings (Liu and Seymour, 1998).

Undoubtedly, the current 'paternalistic' procedure structure in which the police have the sole responsibility for implementing procedural safeguards is dangerous if frequently unchallenged. Though coercive questioning, an extreme means to obtain objective evidence, implies weakness of the daily operations of the police, ${ }^{44}$ it can also be attributed to the 'system' of criminal justice that allows it to exist. As a whole, by relying heavily on confession to solve crimes, law enforcement is able to divert the available funds to other arguably more productive uses..$^{45}$

\section{Interrogational Paternalism}

Second, on a micro level within the interrogation space, the relationship between the interrogator and the suspect has been and continues to be

\footnotetext{
${ }^{44}$ Specifically, the daily operations of the police are undermined by budget shortages (Zhu, 2006; Chen, 2007) and poorly trained police officers (Wang, 2006); the police force is undersized and functions by using underdeveloped investigative methods (Zuo and Zhou, 2002; Wu, 2008).

${ }^{45}$ Chen (2007: 59) has argued that the importance of increasing national investment in criminal investigation has never been fully recognized by the Chinese government. Since the advent of an open economy and a reform policy, the government's financial input in criminal investigations concerning personnel or technology has not increased concurrently with the significant rise in crime as well as the changes in crime patterns. Owing to a limited budget, some forensic techniques, like DNA testing, cannot be employed in crime investigation procedure (Chen, 2007).
} 
'paternalistic'. The attitude of criticizing wrongdoers for their unwillingness to repent for and admit to the crime facts, derived from the familist or paternalism tradition, continues to offer plenty of psychological comfort to the police. Although the 'open-door' policy has increased individualism in China, to a large extent, Confucian doctrines of xiao (孝) and family loyalty still strongly influence the modern Chinese family relationships (Whyte and Parish, 1984). It was suggested that the Chinese family often dominates individuals by forcing them to come to terms with family values and tradition ( $\mathrm{Lu}$, Zhang and Miethe, 2002). Given such moral cultivation, according to Fairbank (1987:31-32), 'Chinese well habituated to the family system have been prepared to accept similar patterns of status in other institutions, including the official hierarchy of the government'. As a current research of court questioning in China shown, in Chinese criminal courtrooms questioning discourse is a persuasive process of obtaining a confession from defendants. To achieve the persuasive purpose, the presiding judge and procuratorate using various patterns of questioning in order to accuse and attack defendants' moral senses in order to elicit confession or remorse (Chang, 2004, 718-719). Similarly, in the interrogation room, the suspect's submissive and honest attitude seems to be considered legitimate and morally valid by interrogators. In addition, the societal view on crime and wrongdoers ${ }^{46}$ gives law enforcement 'additional moral legitimacy to take measures to coerce confessions and press for repentance' (Ren, 1997:132). As a survey conducted in 2006 shows, the public's attitude towards pernicious police interrogation practices is tolerant, and even supportive (Lin, Zhao, and Huang, 2006: 133-4).

\section{Conclusion}

Ancient Greece and China differed markedly in their systems of thought. Greeks tended to engage in context-independent and analytic perceptual processes by focusing on a salient object (or person) independently of its context, whereas

46 The CPL declares that "the use of torture to extort confession and the collection of evidence by threats, enticement, deceit or other unlawful methods is strictly prohibited" (CPL, Art. 43). Further, torture is a crime, and the torturer can in serious cases be punished by life imprisonment or death (CCP, Art. 247, 234, 232). The stiff penalties, however, have not had much deterrent effect on police officers. Research based on interviews with police officers reports that Chinese police do not generally think of themselves as evil but rather seem to feel that coercing confessions is justified and they regard themselves as the guardians of the interests of society in combating crime and criminals (Wang, 2002; Wu, 2006b). It was observed that the police often abused Article 96 of the 1996 CPL to set the time and place for the lawyer-suspect meeting and be present at the meeting (Liu and Halliday, 2009). Notably, some senior ranks also share a similar view that the ends-convicting criminals-justify the means (Lin, Yu and Zhang, 2006). Wu (2006b: 161) discovered that legal authorities showed leniency towards the police involved in interrogational 'torture' cases, and the punishment rarely corresponded to the severity of the crime. 
Chinese tended to engage in context-dependent and holistic perceptual processes by attending to the relationship between the object and the context in which the object was located. These two ancient civilizations in fact resulted in great difference between Europe and China in terms of their legal cultures and the institutional arrangements of their criminal justice systems.

Europe believed fundamental law was itself divinely instituted and favoured a rational legal system in which law served as a systematic means to define jurisdictions. Since the boundaries of jurisdictions were clarified, law factually provided the formal means by which both legal officials and individual suspects could preserve personal spheres of power in criminal interrogations. Specifically, under medieval law, the rights of the accused were mainly based upon a purportedly objective assessment of the teachings of authoritative materials. Nonetheless, in modern Europe, individual rights and internal independence are highly respected. Hence, the principles of the right to silence and the privilege against self-incrimination were raised and seen as an expression of individual autonomy - the right of the accused to be respected as an individual throughout the criminal process and to reach an autonomous decision when called upon to answer to criminal allegations.

In contrast, the Chinese, without transcendental sources of legitimation and under the strong influence of Confucian thought, built their legal system on assumptions of harmony among hierarchically arranged players. Precisely, in the imperial criminal procedure individuality was defined in terms of one's responsibility to explicitly defined roles. The suspect, as a subordinate member in the family, had the obligation to be obedient and admit his moral guilt. The judge or magistrate, as the head of a family, had the authority and obligation to persuade the suspect to change his mind and confess based on evidence and patience. Hence, in theory, power is impersonal, non-intentional, and directed towards maintaining the harmony of the whole. In developmental terms, this line of reasoning emphasized the collective and intuitive sides of life and led to the specification of roles and of role-defined actions and emotions, a trend that in turn reduced the legitimate discretionary spheres of individual action. Consistent with the traditional Chinese legal culture, the suspect's behaviour under the current Chinese interrogation procedure continues to be 'restricted' 47 by the pertinent relationships that demand obedience, that is, honesty, during the questioning process.

Considering future legal reforms in China, given the very different historical and institutional context, the likelihood of an 'autonomous version' of the right to silence and the privilege against self-incrimination in China's very different

${ }^{47}$ There is no provision in the law as to the consequences that follow from a suspect's silence, such as the fact finder drawing unfavourable inferences from a passive reaction. 
soil seems low. In the reform era, as indicated, the attitude of being honest about one's misconduct, and submissive to authority have continued to be reinforced by Chinese familism, especially the concept of xiao (孝). This is not to say that other external pressures of the kind mentioned at the beginning of this papersuch as the pressure on the PRC to comply with the 'universal' norms-will not make the content of new interrogation rules profoundly different from that of the past, difficult as this may be to accomplish. As long as the familist and societal view of crime and wrongdoers holds sway, the real question is whether new content can overcome hoary practices, values, and interpretations. Notably, although the 2012 CPL, which takes effect on 1 January 2013, highlights the principle of protecting human rights in the criminal proceedings (Art. 2), the law continues to emphasize the importance of being honest in police interrogation. Article 118 of the 2012 CPL provides that 'the criminal suspect shall answer the investigators' questions truthfully'. Furthermore, a new paragraph is added as Paragraph 2 to Article 118, which reads: 'when interrogating criminal suspects, investigators shall inform the criminal suspect of the legal provisions allowing for leniency for those who truthfully confess their crimes'. At this point, it should be noted that Chinese law was embedded in an altogether different ideological context than the one that gave rise to the right to remain silent in the West. As already seen, the imperial Chinese law is largely moralistic in nature. Since the Han dynasty, Confucian's moral standards, particularly those dealing with contrition, patriarchal relationships and familial obligations, started to become a part of the content of law, and legalist's reward and punishment machineries became the instruments for executing such content. Hence, the better way to comprehend the above mentioned provisions is not to consider them manifestations of caprice on the part of the present Chinese leadership, but rather to recognize them as expressions of the inherent Chinese legal attitude which the Chinese lawmakers want to respect and enhance. Pound (1948: 751) once emphasized that many plausible legal reform projects have been slow in achieving their purposes, and more than a few have failed, because they break with the past too violently or fail to take into account long-settled habits of thought of action. Therefore, if the 'human rights' standards would be interpreted and applied in the Chinese context, it is crucial to remember that legal precepts have to be fitted to the lives of the people they are to govern, not the lives of people arbitrarily fitted to the legal precepts.

As Posner (1990) rightly argues, laws are not abstract, sacred entities, but socially determined goads for shaping behaviour so as to conform to society's values. Indeed, there can be no wisdom in the choice of a path unless one knows where it will lead. Based on this paper's preceding analysis, it may well be established that traditional Chinese moral values are supportive of an ethical approach to criminal investigation and a cooperative interviewing style in questioning the suspect. Similarly, in many Western countries, there is a tendency to use the concept of 'investigative interviewing' as an alternative to interrogation. For instance, in the United Kingdom (UK), the expression 
'investigative interviewing' is used to describe questioning of suspects and victims, as well as witnesses, at any point in the investigative process (Williamson, 1993; Gudjonsson, 1994). Underpinning the new approach of criminal interviewing is a firm commitment to move from questioning purely to obtain a confession, towards questioning that is more of an inquiry-examining and adding to the existing evidence (Williamson, 1993). This change is a result of the combined effects of new legislation, psychological development, and organizational policies designed to make the questioning of a suspect less inherently coercive. It is hoped that this ethical approach to investigation would elicit reliable information and factual accounts from a person about an alleged offence (Brewer and Williams, 2005).

Therefore, in any event, many of the most pressing obstacles for the implementation of fair interrogation standards in China have nothing to do with Confucian philosophies. Rather, they are institutional in nature. Historically, Chinese leadership, through the interplay between Confucianism's moral standards and legalist bureaucracy, relied heavily on informal means to maintain social order and settle disputes, and established a powerful, minimalist law enforcement authority, which was responsible only for conflicts that could not be solved by informal mechanisms and for serious crimes. On the whole, this social control model, which required tremendous 'faith' in the credibility of the judicial authorities, failed to adequately address the need to protect individuals against law enforcement interrogation practices that were abusive or overreaching, and therefore indirectly contributed to the prevalence of policecoerced confession both in the past and present. In light of this, how traditional moral obligations, for both the interviewer and interviewee, could best be combined with institutional restrictions, should be a central concern underlying future research on interrogative practices within the Chinese criminal justice system. Since it has been long recognized in the West that standing legal orders and forced instructions have a limited effect on police questioning (Leo, 1992; Gudjonsson, 1994), it may well prove to be an advantage that China already has a traditional moral philosophical body of ethical customs. As we have already seen, there is a strong emphasis in the Chinese criminal justice system on proper planning and preparation prior to questioning and on personal integrity ${ }^{48}$ during questioning. This body of customs may become a body of ideals around which the adjustment of relations and ordering of conduct in criminal interviewing may be shaped.

\footnotetext{
${ }^{48}$ As observed, there is a strong emphasis in the Chinese criminal justice system on the moral duty of both legal officials and individual suspects to conform to their roles in order to eliminate ambiguity and arrive at the 'truth' in criminal interviewing. Moreover, Confucian's relationships also stress a sense of reciprocity (bao 报), that is, those who have increased authority shall also have increased responsibilities.
} 


\section{References}

Alford, W. P. (1984). Of Arsenic and Old Laws: Looking Anew at Criminal Justice in Late Imperial China. California Law Review, 72, 6, 1180-1256.

Ansley, C. (1986). Chinese criminal law under Manchus and Marxists. University of British Columbia Law Review, 165-191.

Baldwin, J. W. (1961). The Intellectual Preparation for the Canon of 1215 against Ordeals. Speculum: a Journal of Mediaeval Studies, 36, 4, 613-636.

Bao, R.-W., \& Chelminski, R. (1973). Prisoner of Mao. New York: Coward, McCann \& Geoghegan.

Bary, W. T. (1995). The "Constitutional Tradition" in China. Columbia Journal of Asian Law, 9, 7-34.

Beattie, J. M. (1991). Scales of Justice: Defense Counsel and the English Criminal Trial in the Eighteenth and Nineteenth Centuries. Law and History Review, 9, 2, 221-267.

Berman, H. J. (1983). Law and revolution: The formation of the Western legal tradition. Cambridge, Mass: Harvard University Press.

$\mathrm{Bi}$, X. Q. (2007). Legal Regulations on the Investigative Interrogation [zhenchaxunwen guocheng falvwenti yanjiu]. Journal of Chinese People's Public Security University, 125, 130-136.

Bodde, D., \& Morris, C. (1967). Law in Imperial China. Camb., Mass: Harvard U.P.

Brewer, N., \& Williams, K. D. (2005). Psychology and law: An empirical perspective. New York: Guilford Press.

Brown, P. (1975). Society and the Supernatural: A Medieval Change. Daedalus, 104, 2, 133-151.

Cape, E., Namoradze, Z., Smith, R. \& Spronken, T. (2010). Effective Criminal Defence in Europe. Intersentia Uitgevers N V.

Chang, Y. (2004). Courtroom Questioning as a Culturally Situated Persuasive Genre of Talk. Discourse \& Society, 15, 6, 705-722.

Chen, Y. S. (2000). Against Torture - the Rule of Law and Human Rights Protection in Modern China. Bei Jing: Social Science Academic Press. 
Chen, Y. S. (2007). A Perspective of China's Criminal Misjudgment [woguo xingshiwupan wentitoushi]. China Legal Science, 137: 45-61.

Clark, G. (2008). An Introduction to the Legal Profession in China in the Year 2008. Suffolk University Law Review, 41, 4, 833-850.

Cohen, L. J. (1983). Freedom of proof. In Facts in law: Association for Legal and Social Philosophy Ninth Annual Conference at Hatfield College, University of Durham, 2nd-4th April 1982 (pp.1-21). Wiesbaden, Germany: Franz Steiner Verlag.

Connery, J. R. (1955). The Right to Silence. Marquette Law Review, 39, 180-190.

Cromer, A. (1993). Uncommon Sense: The Heretical Nature of Science. New York: Oxford University Press.

Cui, M. (2003). Holding Back Interrogational Torture [zailun ezhi xingxunbigong]. Journal of Zhejiang Police College - Public Security Science Journal, 76, 24-29.

Damaska, M. (1973). Evidentiary Barriers to Conviction and Two Models of Criminal Procedure: A Comparative Study. University of Pennsylvania Law Review, 121, 3, 506-589.

Damaska, M. (1978). The Death of Legal Torture. Faculty Scholarship Series. Paper $1587,860-884$.

Damaska, M. (2005). Assignment of Counsel and Perceptions of Fairness. Journal of International Criminal Justice, 3, 1, 3-8.

Dikötter, F. (2002). Crime, Punishment and the Prison in Modern China. London: C. Hurst \& Co. (Publishers) Ltd.

Dutton, M. (2000). The end of the (mass) Line? Chinese policing in the era of the contract. Social Justice, 27, 2, 61-105.

Engels, F. (1979). Letter to van Patten, 18.4.1833. In M. Cain \& A. Hunt (Eds.), Marx and Engels on Law (pp. 164-165). London: Academic Press.

Esmein, A., Mittermaier, C. J. A. \& Garraud, R., (2010). A History of Continental Criminal Procedure, with Special Reference to France. CAROLINA: Nabu Press.

Fairbank, J. K. (1987). The great Chinese Revolution: 1800-1985. London: Chatto \& Windus. 
Finer, S. E. (1999). The History of Government from the Earliest Times: Vol. 1. Oxford: Oxford University Press.

Fraher, R. M. (1989). Conviction According to Conscience: The Medieval Jurists' Debate concerning Judicial Discretion and the Law of Proof. Law and History Review, 7, 1, 23-88.

Fu, H. L. (1998). Criminal Defence in China: The Possible Impact of the 1996 Criminal Procedural Law Reform. China Quarterly, 153, 31-48.

Fung, H. (2006). Affect and Early Moral Socialization: Some Insights and Contributions from Indigenous Psychological Studies in Taiwan. In U. Kim, K. K. Hwang, \& K. S. Yang (Eds.), Indigenous and Cultural Psychology: Understanding People in Context (pp. 175-196). Boston, MA: Springer Science + Business Media.

Fung, Y. (1983). A History of Chinese Philosophy (D. Bodde, Trans.) (Vol. 1-2). Princeton, NJ: Princeton University Press.

Galtung, J. (1981). Structure, Culture, and Intellectual Style: An Essay Comparing Saxonic, Teutonic, Gallic and Nipponic approaches. Social Science Information, 20, 817-856.

Gelatt, T. A. (1982). The People's Republic of China and the Presumption of Innocence. Journal of Criminal Law and Criminology, 73, 1, 259-316.

Grant, G. (1989). The Family and Social Control: Traditional and Modern. In R. J. Troyer, J. P. Clark,\&D. G. Rojek (Eds.), Social control in the People's Republic of China (pp. 17-25). New York: Praeger.

Gudjonsson, G. H. (1994). Investigative Interviewing: Recent Developments and Some Fundamental Issues. International Review of Psychiatry, 6, 2, 237-245.

Hamilton, E. (1973). The Greek way. New York: Avon. (Original work published 1930)

Hamilton, G. G. (1984). Patriarchalism in Imperial China and Western Europe: A Revision of Weber's Sociology of Domination. Theory and Society, 13, 3, 393-425.

Hamilton, G. G. (1990). Patriarchy, Patrimonialism, and Filial Piety: A Comparison of China and Western Europe. British Journal of Sociology, 41, 1, 77104.

Hansen. C. (1983). Language and logic in ancient China. Ann Arbor: University of Michigan Press. 
Helmholz, R.H. (1990). Origins of the Privilege against Self-incrimination: the Role of the European Ius Commune. New York University law review, 962-990.

Helmholz, R. H. (1997). The Privilege against Self-incrimination: Its Origins and Development. Chicago: University of Chicago Press.

Helmholz, R. H. (2002), Natural Human Rights: the Perspective of the Ius Commune. Catholic University Law Review, 52, 301-326.

Jackson, J. D. (1988). Two Methods of Proof in Criminal Procedure. Modern Law Review, 51, 5, 549-568.

Jackson, J. D. (2009). Re-Conceptualizing the Right of Silence as an Effective Fair Trail Standard. International and Comparative Law Quarterly, 58, 4, 835-861.

Jamieson, G. S. (1921). Chinese Family and commercial Law. Shanghai: Ketty \& Walsh.

Jiang, S., Lambert, E., \& Wang, J. (2007). Correlates of Formal and Informal Social/Crime Control in China: An Exploratory Study. Journal of Criminal Justice, $35,3,261-271$.

Jiao, A. Y. (2001). Police and Culture: A Comparison between China and the United States. Police Quarterly, 4, 2, 156-185.

Knox, B. (1990). Introduction to Homer's Iliad (Robert Fagles, Trans.). St. Paul, MN: Penguin-High Bridge.

Langbein, J. H. (1977), Torture and the Law of Proof: Europe and England in the Ancien Régime. Chicago: University of Chicago Press.

Langbein, J. H. (1994). The Historical Origins of the Privilege against SelfIncrimination at Common Law. Michigan Law Review, 92, 5, 1047-1085.

Langbein, J. H. (2004). The Legal History of Torture. In Levinson, S. (Eds.), Torture: A collection (pp. 93-103). Oxford: Oxford University Press.

Leng, S.-C. (1982). Criminal Justice in Post-Mao China: Some Preliminary Observations. Journal of Criminal Law and Criminology, 73, 1, 204-237.

Leo, R. A. (1992). From Coercion to Deception: the Changing Nature of Police Interrogation in America. Crime, Law and Social Change, 18, 35-39.

Lesaffer, R., \& Arriens, J. (2009). European Legal History: A Cultural and Political Perspective. Cambridge, UK: Cambridge University Press. 
Levy, L. W. (1968). Origins of the Fifth Amendment: The Right against Selfincrimination. New York: Oxford University Press.

Lloyd, G. E. R. (1990). Demystifying mentalities. New York: Cambridge University Press.

Lloyd, G. E. R. (1991). The invention of nature. In G. E. R. Lloyd (Ed.), Methods and problems in Greek Science (pp. 417-434). Cambridge, England: Cambridge University Press.

Lin, L. H., Yu, T. \& Zhang, C. (2006). Survey Report: Social Cognition of Extorting Confessions by Torture-The Police [xingxunbigong shehuirenzhi baogao-jingcha juan]. Law Review, 139, 123-140.

Lin, L. H., Zhao, Q. L., \& Huang, Q. H. (2006). Survey Report: Social Cognition of Extorting Confessions by Torture -The General Public [xingxunbigong shehuirenzhi baogao-minzhongjuan]. Law Review, 138, 117-135.

Liu, S., \& Halliday, T. C. (2009). Recursivity in Legal Change: Lawyers and reforms of China's Criminal Procedure Law. Law and Social Inquiry, 34, 4, 911950.

Liu, Y. D., \& Seymour, J. D. (1998). Guest Editors' Introduction. Chinese Law and Government, 31, 3, 3-7.

Lu, H., \& Drass, K. (2002). Transience and the disposition of theft cases in China. Justice Quarterly, 19, 1, 69-96.

Lu, H., \& Miethe, T. D. (2003). Confessions and Criminal Case Disposition in China. Law and Society Review, 37, 3, 549-578.

Lu, H., Zhang, L., \& Miethe, T. D. (2002). Interdependency, Communitarianism and Reintegrative Shaming in China. The Social Science Journal, 39, 189-202.

Ma, H. H. P. (1987). The legalization of Confucianism and its impact on family relationships. Washington University law quarterly, 65, 4, 667-679.

Ma, H. J., \& Li, B. T. (1999). Procedure Instrumentalism and Interrogational Torture [chengxu gongjuzhuyi yu xingxunbigong]. Law Journal of Shanghai Administrative Cadre Institute of Politics and Law, 63, 63-65.

Ma, Y. (1997). The Police Law 1995: Organization, Functions, Powers and Accountability of the Chinese Police. Policing, 20, 1, 113-135. 
Ma, Y. (2003). The Powers of the Police and the Rights of Suspects under the Amended Criminal Procedure Law of China. Policing: An International Journal of Police Strategies \& Management, 26, 3, 490-510.

Ma, Y. (2007). A Comparative View of the Law of Interrogation. International Criminal Justice Review, 17, 1, 5-26.

MacCormack, G. (1987). Liability of Officials under the Tang Code. Hong Kong Law Journal, 17, 142-162.

Macnair, M. R. T. (1990). The Early Development of the Privilege against SelfIncrimination. Oxford Journal of Legal Studies, 10, 1, 66-84.

McCormick, C. T. (1954). Handbook of the Law of Evidence. St. Paul, Minn: West Publishing.

Moise, E. E. (1994). Modern China: A History. New York: longman.

Munro, D. J. (1969). The Concept of Man in Early China. Stanford, CA: Stanford University Press.

Nelken, D. (2001). Towards a Sociology of Legal Adaptation. In Nelken, D., \& Feest, J. (Eds.), Adapting Legal Cultures (pp. 7-54). Oxford: Hart Pub.

Nisbett, R. E., \& Miyamoto, Y. (2005). The Influence of Culture: Holistic versus Analytic Perception. Trends in Cognitive Sciences, 9, 10, 467-73.

Nisbett, R. E., Peng, K., Choi, I., \& Norenzayan, A. (2001). Culture and systems of thought: holistic versus analytic cognition. Psychological Review, 108, 2, 291310.

O'Reilly, G. W. (1997). Comment on Ingraham's "Moral Duty" to Talk and the Right to Silence. Journal of Criminal Law and Criminology, 87, 2, 521-543.

Peerenboom, R. (2002). China's long march towards rule of law. Cambridge Press.

Peerenboom, R. (2003). Beyond Universalism and Relativism: The Evolving Debates about Values in Asia. Indiana International and Comparative Law Review, $14,1-86$

Peerenboom, R. (2004). Competing Conceptions of Rule of Law in China, in Peerenboom, R. P. (Eds.), Asian Discourses of Rule of Law: Theories and Implementation of Rule of Law in Twelve Asian Countries, (pp.113-145). France, and the U.S. London: Routledge. 
Peerenboom, R. (2006). Law and Development of Constitutional Democracy: Is China a Problem Case?. The Annals of the American Academy of Political and Social Science, 603, 1, 192-199.

Peters, E. (1985). Torture. New York: B. Blackwell.

Pieck, M. (1962). The Accused's Privilege against Self-Incrimination in the Civil Law. The American Journal of Comparative Law, 11, 4, 585-601.

Pollock, F., \& Maitland, F. W. (1898). The History of English Law before the Time of Edward I. Cambridge: The University press.

Posner, R. A. (1990). The Problems of Jurisprudence. Cambridge, Mass: Harvard University Press.

Pound, R. (1948). Comparative Law and History as Bases for Chinese Law. Harvard Law Review, 61, 5, 749-762.

Ren, X. L. (2007). The Barriers to the Application of Synchronous Recording of Interrogation [xunwen tongbu luyinluxiang zhidu zai woguo shishi de zhangai]. Journal of Shandong Police College, 94, 65-68.

Rickett, W. A. (1971). Voluntary Surrender and Confession in Chinese Law: The Problem of Continuity. The Journal of Asian Studies, 30, 4, 797-814.

Rojek, D. (1985). The Criminal Process in the People's Republic of China. Justice Quarterly, 2(1), 117-125.

Rommen, H. A., \& Hanley, T. R. (1947). The Natural Law: A Study in Legal and Social History and Philosophy. St. Louis, Mo: B. Herder Book Co.

Roth, K. (2008). Why the Current Approach to Fighting Terrorism Is Making Us Less Safe. Creighton Law Review, 41, 4, 579-594.

Stein, P. (1999). Roman Law in European History. New York: Cambridge University Press.

Summers, S. J. (2007). Fair trials: The European criminal procedural tradition and the European Court of Human Rights. Oxford: Hart.

Tamanaha, B. Z. (2004). On the Rule of Law: History, Politics, Theory. Cambridge: Cambridge University Press. 
Theophilopoulos, C. (2003). The Historical Antecedents of the Right to Silence and the Evolution of the Adversarial Trial System. Stellenbosch Law Review, 14, 161-144.

Tierney, B. (1997). The Idea of Natural Rights: Studies on Natural Rights, Natural Law, and Church Law, 1150-1625. Atlanta, Ga: Scholars Press.

Toulmin, S., \& Goodfield, J. (1961). The Fabric of the Heavens: The Development of Astronomy and Physics. New York: Harper and Row.

Trechsel, S., \& Summers, S. J. (2005). Human Rights in Criminal Proceedings. Oxford England: Oxford University Press.

Van Kessel, G. (1998). European Perspectives on the Accused as a Source of Testimonial Evidence. Western Virginia Law Review, 100, 799-845.

Wang, M. (1997). The Methods and Significance of the Modification of Laws in the Late Qing Dynasty [lun qingmo xiulv de fangfa yu yiyi]. Journal of Nanjing Normal University (Social Science Edition), 95, 37-41.

Wang, M. (2002). Psychological Causes of Interrogational Torture and Restraint Measures [minjing xingxunbigong de xinlizhuangtai jiqijiaozhi]. Journal of Hubei Police Officer College, 68, 34-36.

Wang, Z. C. (2006). Tackling the Persistent Ailment of Interrogational Torture [zhiyizhi xingxunbigong zheyiwanzheng]. People's Procuratorial Semimonthly, 1199, $15-21$.

Weber, M. (1968). Economy and Society. New York: Bedminster Press.

Wei, P. (2003). Criminal Investigation and Interrogation. Beijing: China University of Political Science and Law Press.

White, W. S. (2001). Miranda's Waning Protections: Police Interrogation Practices after Dickerson. Ann Arbor: University of Michigan Press.

Whyte, M. K., \& Parish, W. L. (1984). Urban Life in Contemporary China. Chicago: University of Chicago Press.

Wieacker, F. (1981). The Importance of Roman Law for Western Civilization and Western Legal Thought. International and comparative law review, 4, 257-281.

Wieacker, F. (1990). Foundations of European Legal Culture. The American Journal of Comparative Law, 38, 1, 1-29. 
Williams, J. W. (2000). Interrogating Justice: A Critical Analysis of the Police Interrogation and its Role in the Criminal Justice Process. Canadian Journal of Criminology, 42, 209-240.

Williamson, T. M. (1993). From Interrogation to Investigative Interviewing; Strategic Trends in Police Questioning. Journal of Community \& Applied Social Psychology, 3, 2, 89-99.

Windrow, H. (2006). A Short History of Law, Norms, and Social Control in Imperial China. Asian-Pacific Law \& Policy Journal, 7, 244-301.

Wong, K. C. (2001). Community Policing in China: Philosophy, Law and Practice. International Journal of the Sociology of Law, 29, 2, 127-147.

Wu, D. H. (2006a). A Positive Study of Exclusion of Illegally Obtained Evidence: Cases Concerning Using Torture to Coerce Confessions [feifazhengju paichuguize de shizhengyanjiu-yifayuan chuli xingxunbigong bianhuweili]. Modern Law Science, $147,143-149$.

Wu, D. H. (2006b). Role, Situation and Sustainability-Analyzing Interrogational Torture from a Socio-Legal Perspective [juese, qingjing yu shehuirongrenfashehuixue shiyezhongde xingxunbigong wenti]. Peking University Law Journal, 104, 147-169.

Wu, J. K. (2008). The Permitting Study of Duplicity Interrogating [qipianxing xunwen rongxuxing yanjiu]. Journal of Jiangxi Public Security College, 118, 28-35.

$\mathrm{Wu}, \mathrm{W}$. (2011). Interrogational Fairness under the European Convention on Human Rights, International Journal of Law, Crime and Justice, 39, 37-59.

Wu, W., \& Vander Beken, T. (2010). Police Torture in China and its Causes: A Review of Literature. The Australian and New Zealand Journal of Criminology, 43, 3, 557-579.

Wu, W., and Vander Beken, T. (2012). The Evolution of Criminal Interrogation Rules in China. International Journal of Law, Crime and Justice, in Press.

Yu, P. (2002). Glittery Promise vs. Dismal Reality: The Role of a Criminal Lawyer in the People's Republic of China after the 1996 Revision of the Criminal Procedure Law. Vanderbilt Journal of Transnational Law, 35, 3, 827-865.

Zander, M. (1990). The Police and Criminal Evidence Act 1984. London: Sweet \& Maxwell Police Review Pub. Co. 
Zhe, F. M. (2005). The Exclusionary Rule for Involuntary Oral Statements-From the Perspective of Torture [feiziyuankougong de paichuguize-cong xingxunbinggong jiaodu de fenxi]. Legal Forum, 96, 26-29.

Zhou, G. X. (1990). Chinese Traditional Philosophy. Beijing: Beijing Normal University Press.

Zhu, S. L. (2007). Political Parties in China's Judiciary. Duke Journal of Comparative \& International Law, 17, 2, 533-560.

Zhu, X. Q. (2006). Personal Reflections on Lawyer's Presence during Criminal Interrogations [zhenchaxunwenshi lvshi zaichang zhiwojian]. People's Procuratorial Semimonthly, 1210, 15-18.

$\mathrm{Zu}$, W. (2008). Primary Rules on Criminal Evidence in Ancient China and its Theoretical Basis [zhongguo gudai jugongdingzui xingshizhengju shouyaoguize ji lilunjiexi]. Law \& Social Development, 79, 1, 42-62.

Zuo, W. M. (2005), Elimination Interrogational Torture by Legalizing Investigation Works [tuijin fazhihuajianshe ezhi xingxunbigong]. People's Procuratorial Semimonthly, 1178, 7-8.

Zuo, W. M., \& Zhou, H. B. (2002). From Legal to Illegal: An Analysis of Interrogational Torture in Context [conghefa daofeifa: xingxunbigong de yujingfenxi]. Law Science, 552, 31-40. 